\title{
Timing and fragmentation of daily working hours arrangements and income inequality - An earnings treatment effects approach with German time use diary data
}

\author{
Joachim Merz, Paul Böhm and Derik Burgert
}

Joachim Merz, Paul Böhm, Derik Burgert

Department of Economic, Law and Behavioural Social Sciences

Leuphana University Lüneburg

Research Institute on Professions (Forschungsinstitut Freie Berufe, FFB)

Campus Scharnhorststr. 1

21335 Lüneburg, Germany

e-mail: merz@uni-lueneburg.de

\begin{abstract}
Traditional well-being analyses based on money income needs to be broadened by its time dimension. In the course of time the traditional full-time work is diminishing and new labour arrangements are discussed (keyword: flexible labour markets) with consequences on the daily work arrangements. Our study is contributing to the research on economic well-being and working hours arrangements by adding insights into particular daily work effort characteristics and its resulting income distribution. The work effort characteristics we regard is about labour market flexibility with focus on relations between the daily timing of work and its fragmentation, and its consequences on the income distribution. Whereas the first part of our study is describing the distribution of timing and fragmentation of daily work time and its resulting income based on more than 35.000 diaries of the most recent German Time Budget Survey 2001/2002, the second part of our study quantifies determinants of arrangement specific earnings functions detecting significant explanatory patterns of what is behind. The related economic theory is a human capital approach in a market and non-market context, extended by non-market time use, the partner's working condition, social networking as well as household and regional characteristics. The econometrics use a treatment effects type interdependent estimation of endogenous participation in a daily working hour pattern (self-selection) and pattern specific earnings function explanation. The overall result: Individual earnings in Germany are dependent on and significant different with regard to the daily working hours arrangement capturing timing and fragmentation of work. Market and non-market factors are important and significant in explaining participation and earnings thereof.
\end{abstract}

JEL-Codes: J21,J22, J24, D3, D31

Keywords: Time use and inequality, timing and fragmentation of daily work time, daily working hours arrangements, earnings explanation, human capital, market and non-market time use, German Time Budget Survey 2001/2002, time use diary data, treatment effects modelling, selfselection with endogenous selection 


\section{Introduction}

\section{Personal remarks to Andrew Harvey}

"Do you already know this jazz record? It's special." Andy put on another record and we both had another good evening with music and a whisky cheer at his home in Halifax. With a good sense of "a proper use of time" - one of his distinguished advices, promoting Dagfin Aas's IATUR toast, about time use - Andy is linking work and leisure in a compound life - an approach of time use research in general with time as the encompassing dimension and coordinator of all daily activities. While my (Joachim Merz) younger research colleagues Paul Böhm and Derik Burgert had not yet the chance of a more personal contact to Andrew Harvey, nevertheless we all are inspired by Andrew Harvey with regard to our time use research at the Research Institute on Professions (FFB) of the Leuphana University Lüneburg (Germany): Paul Böhm and Derick Burgert have their contact mainly via the research topic here of a fragmented day (see Harvey et al., 2000); Joachim Merz, in addition to the research topic here and many good leisure hours, has known Andy for many years collaborating on work including the assessment of the American Heritage Time Use Data (see eIJTUR time pieces, 2005; Harvey and Croix, 2005; Merz and Stolze, 2008) or as common editors of the electronic International Journal of Time Use Research (www.eIJTUR.org). Both, at work and beyond, it's good to have him looking forward to more common enjoyable hours.

\section{Research topic}

Economic well-being described by income and income inequality is a traditional focus of scientific and public interest. The connected time, however, that individuals have to spend to earn that income is a rather infant research field. ${ }^{1}$ If only the distribution of money income would be regarded, inequality differences would neglect differences in working time efforts with misleading results about ('total') economic well-being. Our study is contributing to research on economic well-being and working hours arrangements by adding insights into particular work effort characteristics and its resulting income distribution. The work effort characteristics we regard are about the raising importance of labour market flexibility. ${ }^{2}$ The focus lies on relations between the daily timing of work and its fragmentation on the one hand, and its consequences on income inequality on the other hand. With our focus on 'who is working

\footnotetext{
But see Merz (2002a,b), Osberg (2002), Merz and Kirsten (1999), Jenkins and O’Leary (1996), Lee (2001), Doiron and Barrett (1996), Burtless (1993).

2 Flexible labour markets are discussed under further various topics. To mention only a few: Atypical working hours (Addison and Surfield, 2009; Lesnard, 2008; Glorieux, Mestdag and Minnen, 2008; Glorieux and Minnen, 2004), social policy and flexible working time (Büssing and Seifert, 1995), firm side working time arrangements (Bauer et al., 2001), time famine and time squeeze (Bonke and Gerstoft, 2005; Sullivan, 2007; Clarkberg and Moen, 2000), time and income poverty (Merz and Rathjen, 2009), working hour tension as the tension between desired and actual working hours (Merz, 2002b; Holst and Schupp, 1994), effects of flexible working hours to leisure and family (Le Bihan and Martin, 2005; La Valle et al., 2002; Townsend, 2001; Garhammer, 1994,) or tax and transfer policy impacts on the working hours in the formal and informal economy (Merz, 1990).
} 
when within a day and its earnings impacts' we go beyond traditional labour market analyses where the working situation is characterized by aggregated and stylized labour force participation attributes in general like full and part time work, shift work, atypical work from work weekly or monthly working pattern.

Overall labour market flexibility shows a remarkable change in working hours arrangements within the last decades showing an erosion of normal working arrangements and a growth of atypical and precarious employment. Whereas 1998 about three of four (72.6\%) had a normal employment in Germany, ${ }^{3}$ there were only two of three $(66 \%)$ of them in a normal employment 2008. The fraction of atypical jobs has grown in that decade from $16.2 \%$ to $22.2 \%$. And, these changes have income consequences for the differently employed: Almost half of the atypical employed have low income (less than two third of the median hourly wage) compared to $11.2 \%$ of the normal employed. And, the risk of poverty (2006) is remarkable higher in atypical jobs (14\%) than in normal jobs (3.2\%) (Federal Statistical Office Germany, 2009). ${ }^{4}$

Though the traditional labour market perspective on weekly or monthly pattern provides important information like the above data about atypical employment, however, many labour market questions require just the daily perspective and its timing of work aspect: What's about the flexibility pattern within the all day living situation? How fragmented is a work day also in case of multiple jobs? What are the impacts of flexibility and fragmentation on social participation and social exclusion? What's about the arrangements of all day personal and family life in particular? What are the consequences of fragmented work days for female labour participation and governmental support of pre-school and school child assistance? With these and more topics the underlying policy relevant general question is how labour market rigidities concerning working time resulting in daily fragmented work is influencing all day individual life and well-being. Once determinants of daily working hours arrangements are detected, a more targeted new economic and social policy will be possible.

Our overall aim to provide quantified information for such daily working hours arrangements and its income consequences will focus - enhancing the paid work perspective - on an additional dimension: we are explicitly interested on the influence of time use patterns beyond paid work such as non-market household activities and social network active engagements and received support.

Analyzing daily timing of work requires a demanding individual data base describing the daily use of time in detail. This data base is available by the new latest German Time Budget Survey 2001/2002 with its more than 35.000 individual time diaries and is the micro data base of our study.

3 Normal employment here is defined as full time job or part time job with more than 20 weekly working hours.

4 A long-run two century discussion of the rise and fall of normal working hours ("Normalarbeitsverhältnisse" in Germany is recently discussed by Pierenkemper (2009). 
In the literature, the timing of work time is accentuated by Hamermesh $(2002,1998,1996 \mathrm{a})$ showing that with 'appropriate data the analysis of time use, labour supply and leisure can move beyond the standard questions of wage and income elasticities of (aggregate) hours supplied' (Hamermesh, 2002, 601). With focus on the daily working hours arrangements the timing and fragmentation of daily work time based on German 1991/92 time use diaries is analyzed by Merz and Burgert (2003a); its development to 2001/02 by Merz and Burgert (2004). Though some insights of German daily working hours arrangements are provided, however, its consequences on income and its distribution needs further analyses: it is the contribution of the paper at hand, an extension to the liberal profession's perspective by Merz and Böhm $(2005,2008)$. Further associated international working time arrangement studies based on time use diaries are e.g. Harvey et al. (2000) comparing four countries in the early 90s (Canada, the Netherlands, Norway and Sweden) or Callister and Dixon (2001) based on the New Zealand Time Use Survey 1998/99. Harvey's work in particular was an important impetus for us to use the power of time use diary information for this in-depth labour market analysis.

Combining the time and income dimension, naturally, our study is embedded within its single dimensions, the general time use research area (Merz, 2009; Merz and Ehling, 1999; Harvey, 1999; Merz, 2002a; or National Research Council, 2000), the labour market research (see the surveys by Blundell and MaCurdy, 1999; Killingsworth and Heckman, 1986; Pencavel, 1986 and Killingsworth, 1983) and the economic well-being and income distribution literature (see Silber, 1999; Champernowne and Cowell, 1998; Sen, 1992; or Atkinson, 1970).

\section{Paper organisation and topics}

Based on diary time use data of the German Time Budget Survey 2001/2002 (Section 2) we describe the daily working hours arrangements into two main dimensions: the timing and fragmentation of daily work time considering core and non-core working episodes and number of working episodes (Section 3). We then analyze the consequences of the daily working hours arrangements to the income distribution (Section 4). The second part of our study quantifies determinants of arrangement specific earnings functions detecting significant explanatory pattern of what is behind. We employ a human capital approach, extended by non-market time use, the partner's working condition, social networking as well as household and regional characteristics. The microeconometrics use a treatment effects type interdependent estimation of participation in a daily working hour pattern (self-selection) and pattern specific earnings function explanation (Section 5). Section 6 concludes.

\section{Data - The German time budget survey 2001/2002}

The following analysis is based on data from the actual German Time Use Survey conducted by the Federal Statistical Office in 2001/02 (Ehling et al., 2001). The main part of the survey 
constitutes the time use diaries. The sample contains 35,813 diaries of 11,962 persons (10 years and older) in 5,171 households. ${ }^{5}$ The duration of the individual activities in the diaries was created according to the recommendation for the European time budget survey: each activity is marked on a timescale which shows ten-minute steps. In addition to the diaries the sample also includes information about household and personal characteristics. ${ }^{6}$

The final data used for the analysis restricts the extensiveness of the original data as follows. Although many retirees and children are working, they often have jobs which contribute only a small share to the total household income. For that reason, we restricted our sample to people aged 15 to 65 . For the sake of consistency, we deleted all observations reporting activities of gainful employment but not reporting any income. After these restrictions the set contains 26,949 diaries of 9,080 persons in 4,553 households. To construct the different categories of daily working hours arrangements in Chapter 3, it is necessary to define those activities belonging to 'work'. In particular, these are: ${ }^{7}$ Main gainful employment, additional gainful employment, extended professional qualification during working time, practical placement.

\section{Daily working hours arrangements - Timing and fragmentation of work}

The traditional 'normal' full time working day, as mentioned, is more and more replaced by different working hours arrangements in the course of time. Whereas there are many studies concerning an overall defined full-time and part-time working arrangement (see our introduction) at least for Germany there are only some studies which inspect the daily working hours situation based on diary data (Merz and Burgert, 2003a, 2004). The very reason is the so far lack of the needed challenging data base, a diary based time use survey, which is available now by the most recent German Time Budget Survey 2001/2002, the data base of our study.

To analyse the daily working hours arrangements we consider two central dimensions: First, information about the timing of work time (the location of the working hours the day), and second, information about the fragmentation of a working day (the number of working episodes). We expect and will investigate the significance of these dimensions of daily working hours arrangements and ask for consequences on the income pattern and the explanation of earnings.

\footnotetext{
Every individual was to write down the course of their day on three days (two weekdays and one Saturday or Sunday).

6 The household characteristics can be divided into three groups: The first group contains information about the equipment of the household, e.g. the number of cars, microwave ovens etc. A second group contains household characteristics that cause special time-use for its members, e.g. people in need of special care. The third group of variables reflects the type of household, i.e. household composition or household income. The personal characteristics include socio-economic information of the respondents as e.g. gender, school leaving certificates, etc.. Another part of the German Time Use Survey consists of information about characteristics leading to time use behaviour, for example if and how long a person regularly helps members of other households. A last group of variables reports self-assessment and plans concerning the subject's time use.

7 We hereby follow as much as possible the international definition chosen by Harvey et al. (2000)
} 
Dimension I - The timing of work

In this dimension daily paid work is mainly done within a core working period. In Germany, most of the working episodes start between $7 \mathrm{am}$ and $8 \mathrm{am}$ and end between $4 \mathrm{pm}$ and $5 \mathrm{pm}$. Consequently we define the period between $7 \mathrm{am}$ and $5 \mathrm{pm}$ as the core working period and the time before and after that core period as the non-core working period. A working day where work mainly is done at this non-core period is the timing aspect of an irregular and 'nonnormal' working day with shift and night work. ${ }^{8}$

\section{Dimension II - The fragmentation of a working day}

Our second dimension is the fragmentation of a working day. To get information about the fragmentation, we used the number of working episodes which are interrupted by a break.

But what is a break? Can ten minutes, say, of work interruption already be regarded as a break or not? It is obvious that the composition of the categories and our results depends on the definition of a break which forms the basis of the calculations. In the following we interpret with German workday situations and with respect to the international study of Harvey et al. (2000) - breaks shorter than 60 minutes as a within work period break and thus as an inherent part of the working time. A break longer than an hour is an unusual break and characterizes a real fragmentation with the possibility of starting another secondary job. A further inspection of the type of breaks is given in section 3.3 below.

An interruption of the working episode by at least one break in addition to core vs. non-core work then is the second disturber of a 'normal' workday and a characteristic of a 'nonnormal' working day.

With these two dimensions of different daily working hours arrangements, the traditional working day can be interpreted as a working day in which work is mainly done within the core period in one working episode without longer interruptions. Combining these two dimensions we get four different categories of daily working hours arrangements, which are in the further focus of our investigation.

\subsection{Daily working hours arrangements in Germany - Combining timing and fragmentation of work}

Combining the two dimensions we get a two by two table of daily working hours arrangements in Germany for 2001/02 in Table 1.

Category I includes ,normal' working days, in which work is mainly done within the core working period and which only consist of one working episode (no interruption by breaks). In contrast here upon the categories II and III differ in exactly one dimension from the definition of a ,normal' working day. So the working days in category II can be described as days with mainly core work, but which are, at the same time, interrupted by at least one break. Working days without breaks showing a work activity mainly outside the core working period are de-

8 This is in line with a similar definition in the international study by Harvey et al. (2000).

elJ TUR, 2009, Vol. 6, No. 2 
scribed by category III. Category IV deviates in both dimensions from the normal case. The persons in this category work outside the core period and with at least one interruption.

\section{Table 1}

Daily working hours arrangement categories by timing of work and fragmentation in Germany 2001/2002

\begin{tabular}{|c|c|c|c|c|}
\hline & \multicolumn{4}{|c|}{ Timing of work } \\
\hline & & Mainly core & Mainly non-core & Total \\
\hline \multirow{10}{*}{ 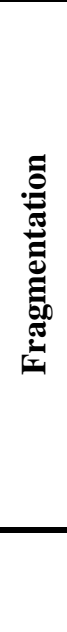 } & & I & III & \multirow{4}{*}{$71.6 \%$} \\
\hline & One & $65.1 \%$ & $6.5 \%$ & \\
\hline & episode & $\mathrm{n}=6,884$ & $\mathrm{n}=716$ & \\
\hline & & $\mathrm{N}=40,503,406$ & $\mathrm{~N}=4,037,688$ & \\
\hline & \multirow{4}{*}{$\begin{array}{c}\text { Two or more } \\
\text { episodes }\end{array}$} & II & IV & \multirow{4}{*}{$28.4 \%$} \\
\hline & & $25.1 \%$ & $3.3 \%$ & \\
\hline & & $\mathrm{n}=2,698$ & $\mathrm{n}=350$ & \\
\hline & & $\mathrm{N}=15,605,547$ & $\mathrm{~N}=2,026,132$ & \\
\hline & & & & $\mathrm{n}=10,648$ \\
\hline & Total & $90.2 \%$ & $9.8 \%$ & $\mathrm{~N}=62,172,772$ \\
\hline
\end{tabular}

Source: German Time Use Survey 2001/02, weighted data, own calculations.

The ,normal' working day is the most frequent case: $65.1 \%$ of all working persons belong to category I. At the same time, however, about 35\% are working outside such a so far normal daily working hours arrangement and might be characterized as atypical working persons. ${ }^{9}$ The prominent category of a ,non-normal' daily working hours arrangement is category II with a share of more than one fourth of all persons $(25.1 \%)$. The most irregular working situation is category IV with about $3.3 \%$ of all workers. About ten percent are working outside the core period $(9.8 \%)$, while $28.4 \%$ of the working days show at least one longer break per working day.

Remarkably, atypical, non-normal daily working hours arrangements have risen in the last decade by about $6 \%$ points to the burden of normal working hours (category I): compared with diary data from the German Time Budget Study 1991/92 the fraction of fragmented working days rose by $4.6 \%$ points (core: $4.0 \%$ points, non-core $0.6 \%$ points) as well as the most irregular non-core/fragmented daily working hours arrangement (1.3\% points).

As expected, the arrangement results vary with different definitions of the minimum length of the breaks (see Appendix Table A1). Defining a break as an interruption of only 30 minutes and more, then only $27.4 \%$ of all working days remain in a normal workday compared to $65.1 \%$ by a 60 minute break. Using a break definition with a larger minimum length the number of breaks decreases and so the number of episodes. Obviously the longer the break is,

9 About $60 \%$ (weighted, 16,301 non-weighted cases) of all total population diaries are not working these days and therefore are not part of the following analysis. 
there will be an increasing share of non-fragmented work. For example, 78\% of all would count to a normal working day if using a 90-minute-break definition. ${ }^{10}$ With respect to the German situation, our 60 minute breaks might be a quite good approximation for a nonnormal interruption of a working day, because 'normal' breakfast and lunch time breaks are distinctly less than one hour; more break characteristics are provided in chapter 3.3 supporting our definition.

\subsection{Some characteristics of daily working hours arrangements}

Let us now inspect some more main characteristics of our four daily working hours arrangement categories. For a better understanding, we differentiate between working hours ('working'), temporary interruptions of work ('breaks') and hours in which no work is done ('not working'). The non-working time covers both the period until the first working period and the period after the last working period.

\section{Category I - Core/one episode}

Within category I which includes the 'normal' working days, a working episode lasts $7 \mathrm{~h}$ $40 \mathrm{~min}$ on average. Figure 1 shows the work frequency profile over the entire day. At 7am the assumed starting point of the core-period - more than one third of the persons are working. The most people work in the peak period between 11:10 and 11:20 (90\%). At the end of the core-working period, i.e. at $5 \mathrm{pm}$, more than $28 \%$ of the people are still working.

Figure 1

\section{Daily timing of work - Category I (core/one episode)}

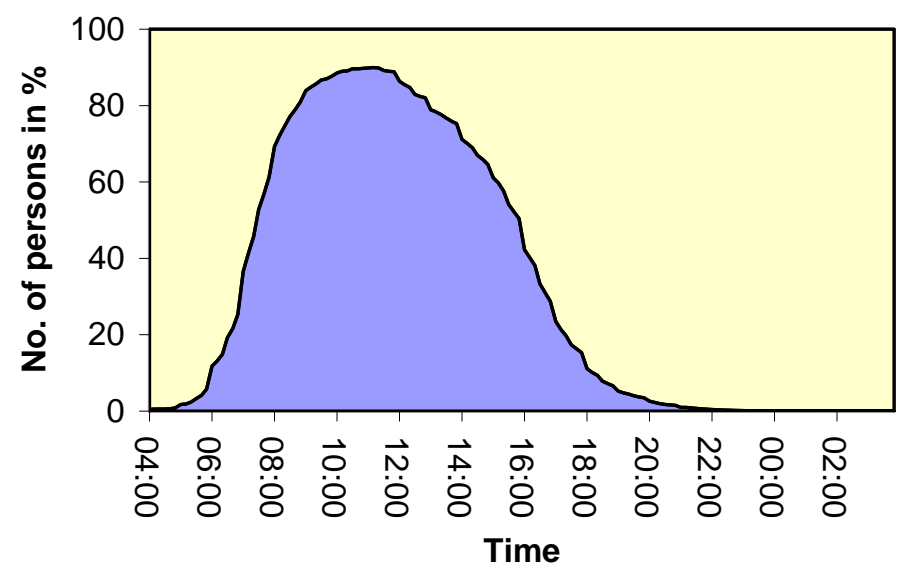

Source: German Time Use Survey 2001/02, own illustration.

\section{Category II - Core/fragmentation with multiple episodes}

This category includes all working days showing mainly core-work activity and with at least one interruption (multiple episodes). On average $7 \mathrm{~h} 22 \mathrm{~min}$ daily are spent for work, whereas almost two and a half hours are spent for breaks on average.

10 See further break duration sensitivity results in the appendix. 
Figure 2 shows the daily timing of work and breaks within this category. At $4 \mathrm{am}$, only $0.7 \%$ of the people are working, while at 7 am already $24 \%$ have started to work. Noticeable are the two peaks of the working curve at 10:40 (share $=88.8 \%$ ) und at $3 \mathrm{pm}($ share $=75.7 \%)$. Between these two peaks, the share of the persons interrupting their working hours reaches its maximum at lunchtime, i.e. in the period between $12: 50$ and $1 \mathrm{pm}$ ( $\operatorname{share}=57.4 \%$ ).

Figure 2

Daily timing of work and breaks - Category II (core/multiple episodes)

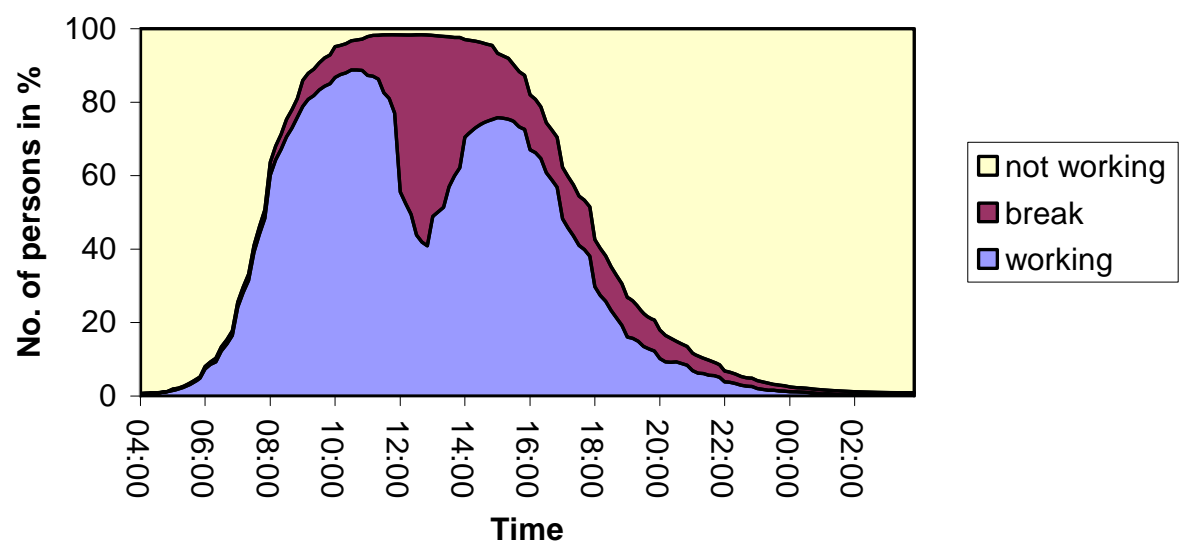

Source: German Time Use Survey 2001/02, own illustration.

\section{Category III - Non-core/one episode}

The average working hours in this category is substantially smaller than in the other categories, only five and a half hours are spent for work. Figure 3 shows that the working hours are situated mainly in the afternoon and evening. The peak of the working curve is at $6 \mathrm{pm}$, when almost two thirds of the people are working ( $\operatorname{share}=64.5 \%$ ).

Figure 3

Daily timing of work - Category III (non-core/one episode)

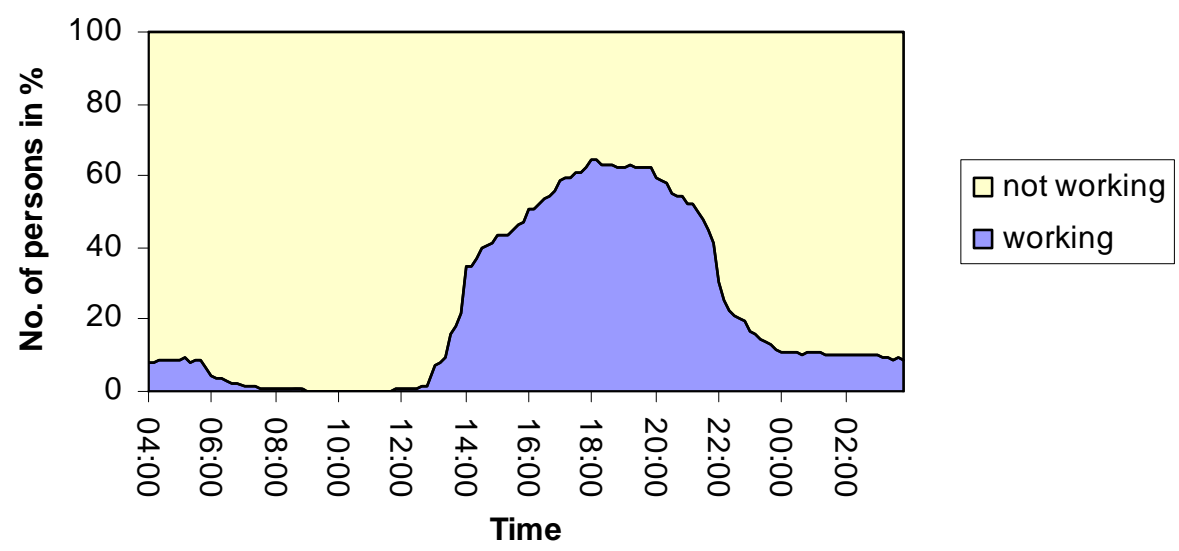

Source: German Time Use Survey 2001/02, own illustration.

Category IV - Non-core/fragmentation with multiple episodes 
The structure of the most irregular working day within category IV is relatively fragmented. The big share of night-work is most remarkable, while the period between $6 \mathrm{am}$ and $4 \mathrm{pm}$ is mainly used for breaks. Hereby it is necessary to mention that the diaries are recorded from 4am on. Changing this specification the analysis would probably bring different results compared to the representation in Figure 4.

\section{Figure 4 \\ Daily timing of work and breaks - Category IV (non-core/multiple episodes)}

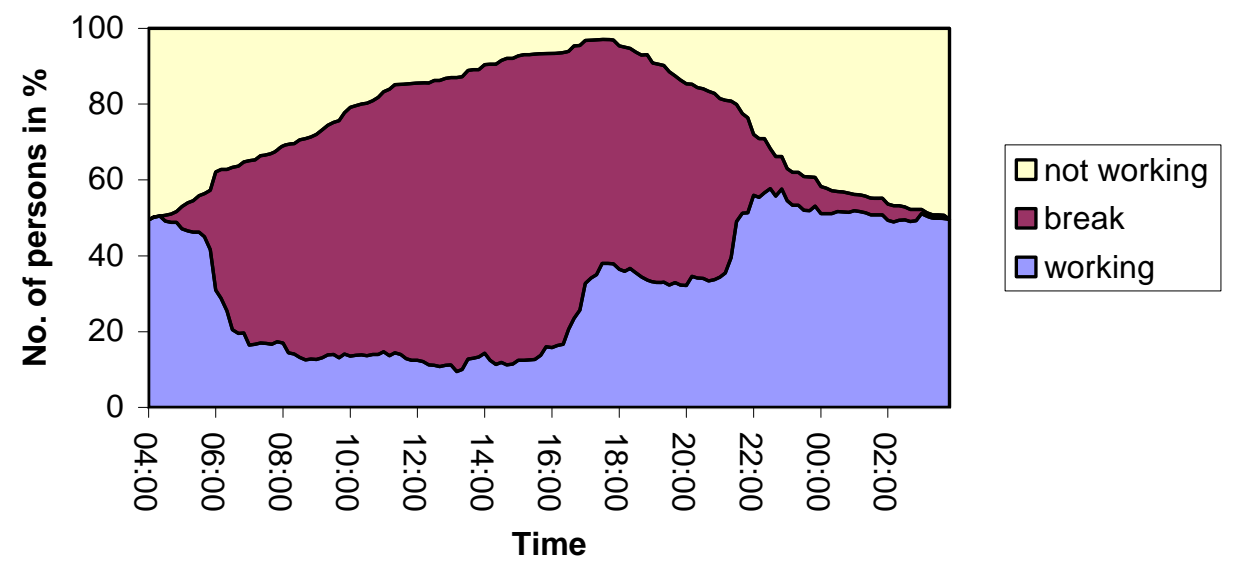

Source: German Time Use Survey 2001/02, own illustration.

In the case of a night-worker, one reason for these expected differences is, according to our definition, that the time between the end (in the morning) and the beginning of a shift (in the evening) has to be interpreted as a break. ${ }^{11}$

\subsection{Activities in the working breaks}

The central question with regard to the characterization of multiple episode working days is the character of the respective breaks. Do they break into different working episodes within the same job, or do they mark the switch to another employment? Unfortunately, by the data at hand we can not distinguish between two employments the day, because a second job flag only is provided in general and not connected by the individual activities of that day in the diary. However, we are able to further characterize the breaks to give some hints of the breaks' characteristics and possible changing employment situations.

As of our categorization, category II (core/multiple episodes) and category IV (noncore/multiple episodes) have more than one working episode. Figure 5 shows the break activities of the persons within these categories. Regardless the core or non-core situation, in both categories the break is mainly used for sleeping, eating and household work. Nevertheless there are partly large differences between these categories regarding their break activities.

11 Figure A1 in the appendix shows the situation when night workers are excluded. Without the persons who are working between 3:50 and 4:10am only 198 cases remain in this category. 
The most irregular working situation of category IV (non-core/multiple episodes) which consists mainly of night-workers has long sleeping breaks. As mentioned above, the period between the end of work time (in the morning after $4 \mathrm{am}$ ) and the start of work (in the evening) of a night-worker has to be interpreted as a break (with the chance to sleep) as well.

In contrast to this, the persons in category II spend the day time between their working episodes besides sleeping and eating mainly with household work and social life.

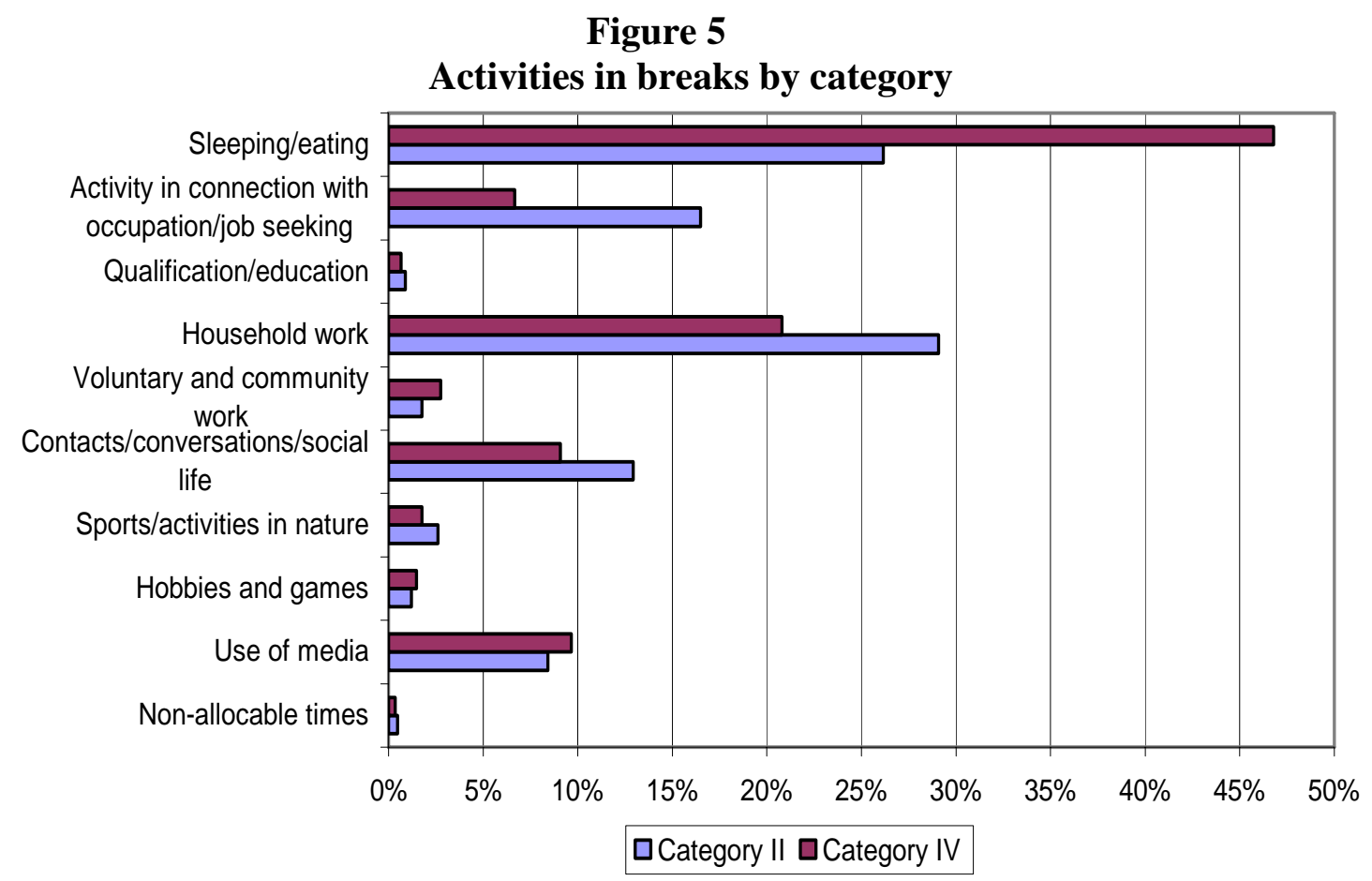

Source: German Time Use Survey 2001/02, own illustration.

To conclude, the inspection of the daily breaks' characteristics does not allow to characterize multiple episodes as multiple jobs directly, however, further aspects of the German working situation and the general second job flag might provide some respective indication (see our microeconometric results).

\section{Daily working hours arrangements, income and its distribution}

We assume and want to disentangle that different daily working hours arrangements result in different income patterns. How do differences in income look like among different working hours arrangements? Are there at all any significant differences in the distribution of net income and what income can be detected when somebody decides for a certain arrangement?

To answer these questions we analyse the income distributions within the four different daily working hours arrangements first by graphic inspection via Kernel density estimates and cen- 
tral distributive measures as well as by Shorrocks' decomposition of inequality. The microeconometric estimation then tries to explain differences.

The available income under inspection is personal net income ${ }^{12}$ which is a person's reported monthly income from main and additional gainful employment after taxes and social insurance contributions of a person. To disentangle the influence of the number of working hours and the wage rate per hour we divide our analysis into the inspection of the income as well the hours and wage distribution.

\subsection{Income distribution and daily working hours arrangements}

The graphical inspection is followed by the discussion of central distributive measures.

Graphic inspection - Kernel income density estimates of daily working hours arrangement

A first graphical inspection of the respective income distributions by Kernel density estimates of monthly net income for the different daily working hours arrangements (Figure 6) in general shows an expected left ascending distribution for all daily working hours arrangements. ${ }^{13}$ However, the pictures differ between categories. The normal working activity pattern of category I (core/one episode) is dominating the average all working profile. More episodes within the core working period result in a shift to the right where higher income are met more frequently.

The non-core workdays result in quite different income distributions compared to the normal workday: lower income is more frequent for the one episode case, higher income is more frequent for multiple episodes.

Thus, the first graphical inspection already shows that our daily working hours arrangement specification is important for the resulting income distribution: different income distributions are the result of different daily working hours arrangements; in particular for the non-core arrangements.

\section{Distributive results by respective measures}

For getting more differentiating results Table 2 provides central income distributive measures $^{14}$ for each single daily working hours arrangements.

The categories with the highest average income are the categories with multiple episodes (categories II: $1,802 €$ and IV: 1,787€). In contrast to this, persons with ,normal' working hours arrangements (category I) have an average income of $1,552 €$, the persons in category III (non-core/one episode) only of $1,320 €$. The median for each category is smaller than the mean

12 Besides announcing his/her exact monthly income each individual had the possibility to indicate his income in income classes. If income information is given in classes, we replace it by their respective mean. To avoid biased results we excluded 41 extreme outliers through which the number of analysed diaries is reduced to 10,607. Among others all diaries with weakly working hours of less than $1 \mathrm{~h}$ were deleted.

13 Different peaks mainly are due to the middle class approximation of bracketed income data.

14 Distributive measures are discussed in Atkinson (1970), Lüthi (1981), Cowell (1995) or Maasoumi (1999). 
indicating a respective left ascending distribution, which is also supported by the positive values of the skewness coefficients.

\section{Figure 6}

\section{Kernel density estimates of monthly net income by different daily working hours arrangements}
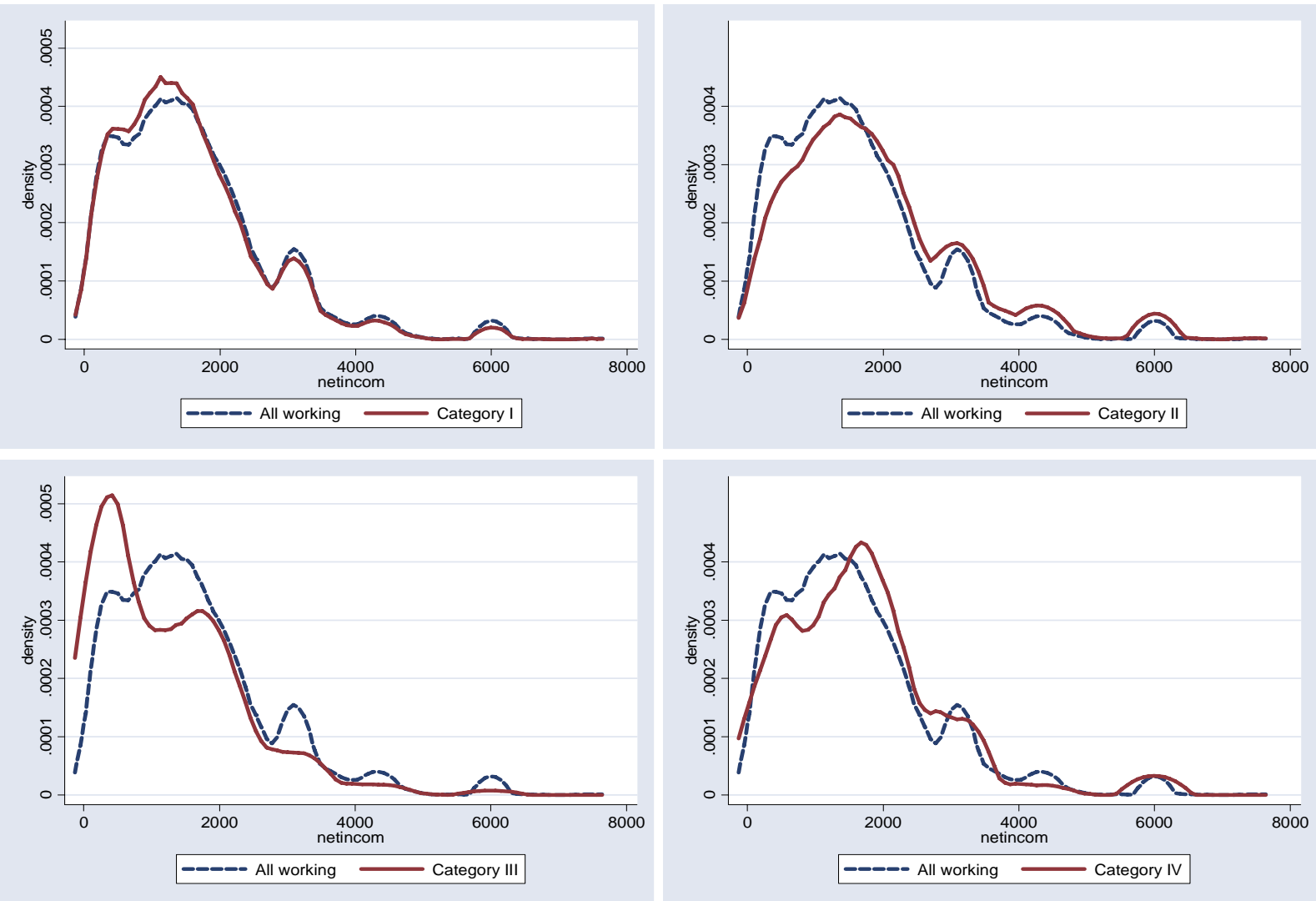

Notes: (core - one episode (1); core - multiple episodes (2); non-core - one episode (3); non-core -multiple episodes (4)); Epanechnikov kernel using optimal band width.

Source: German Time Budget 2001/02, own illustration (Stata 8.2).

There are remarkable income inequality differences between the four daily working hours arrangement categories measured by the Gini coefficients. This is supported by the relative higher Gini coefficients which are sensitive to middle income. The Atkinson-Index is calculated with a relative small $(\varepsilon=1)$ and a relative high $(\varepsilon=2)$ inequality aversion to cover a broad spectrum with a multitude of possible normative evaluations. Both the Gini coefficient and the Atkinson-Index prove category III (non-core/one episode) as the category with the most unequal income distribution. For this category the Gini coefficient amounts to 0.36723 which is by $9.7 \%$ higher than the Gini coefficient for category II, by $16.6 \%$ higher than the one for category I and by even $23 \%$ higher than the one for category IV - the category, surprisingly, with the relatively most equal distribution. The Atkinson-Index, sensitive for lower income, confirms this result. Remarkable is the fact that the Atkinson-Index for the categories I, II and IV does not show any big differences which indicates that the lower income profile of these categories is not very different. Note: Not expected, the most irregular working hours arrangement (non-core/fragmented) results not only in a relatively high but also in the most 
Joachim Merz, Paul Böhm and Derik Burgert: Timing and fragmentation of work and income inequality

equally distributed income. As we will see in addition category IV will show the highest average working hours.

\section{Table 2}

Net income - Distributive measures by daily working hours arrangement

\begin{tabular}{|c|c|c|c|c|c|}
\hline & Working & $\begin{array}{c}\text { Category I } \\
\text { Core } \\
\text { One episode }\end{array}$ & $\begin{array}{c}\text { Category II } \\
\text { Core } \\
\# \text { episodes }>1 \\
\end{array}$ & $\begin{array}{c}\text { Category III } \\
\text { Non-core } \\
\text { One episode }\end{array}$ & $\begin{array}{c}\text { Category IV } \\
\text { Non-core } \\
\text { \# episodes }>1\end{array}$ \\
\hline Mean in $€$ & $1,607.69$ & $1,552.22$ & $1,802.42$ & $1,319.72$ & $1,787.20$ \\
\hline Median in $€$ & $1,431.62$ & $1,380.49$ & $1,556.62$ & $1,252.67$ & $1,636.13$ \\
\hline Skewness & 1.57 & 1.51 & 1.53 & 1.17 & 1.76 \\
\hline Kurtosis & 4.04 & 4.07 & 3.05 & 2.67 & 5.10 \\
\hline Variation coefficient & 0.63 & 0.60 & 0.65 & 0.68 & 0.60 \\
\hline \multicolumn{6}{|l|}{ Distributive measures } \\
\hline Gini coefficient & 0.32563 & 0.31487 & 0.33476 & 0.36723 & 0.29871 \\
\hline \multicolumn{6}{|l|}{ Atkinson-Index } \\
\hline$\varepsilon=1$ & 0.19580 & 0.18435 & 0.19528 & 0.27102 & 0.18412 \\
\hline$\varepsilon=2$ & 0.45425 & 0.43385 & 0.43287 & 0.58784 & 0.45809 \\
\hline \multicolumn{6}{|l|}{$\begin{array}{l}\text { Decile shares in \% } \\
\text { (Decile limits in } € \text { ) }\end{array}$} \\
\hline 1st decile & $1.77(511)$ & $1.88 \quad(511)$ & $1.99(625)$ & $0.98(230)$ & $1.72(625)$ \\
\hline 2rd decile & $4.38(875)$ & $4.53 \quad(875)$ & $4.41 \quad(920)$ & $2.60(500)$ & $4.57(1074)$ \\
\hline 3rd decile & $6.17(1125)$ & $6.33(1125)$ & $5.93(1125)$ & $4.76(750)$ & 7.25 (1375) \\
\hline 4th decile & $7.26(1253)$ & $7.43(1227)$ & $6.88(1351)$ & $6.97(1100)$ & $7.75(1500)$ \\
\hline 5th decile & $8.37(1432)$ & $8.49(1381)$ & $8.05(1557)$ & 8.99 (1253) & $8.42(1636)$ \\
\hline 6th decile & $9.53(1625)$ & $9.63(1585)$ & $9.07(1770)$ & $10.10(1432)$ & $9.70(1875)$ \\
\hline 7th decile & $10.70(1875)$ & $10.69(1790)$ & $10.69(2119)$ & $11.90(1636)$ & $11.08(2000)$ \\
\hline 8th decile & $12.49(2147)$ & $12.50(2125)$ & $12.47(2434)$ & $13.40(1943)$ & $11.66(2375)$ \\
\hline 9th decile & $15.40(3000)$ & $15.18(2812)$ & $15.87(3170)$ & $15.83(2250)$ & $14.71(3125)$ \\
\hline 10th decile & 23.93 & 23.35 & 24.62 & 24.47 & 23.13 \\
\hline 90/10 Relation & 13.52 & 12.42 & 12.37 & 24.97 & 13.45 \\
\hline \multicolumn{6}{|l|}{ Decomposition } \\
\hline Theil Index & 0.18166 & 0.16983 & 0.18846 & 0.23217 & 0.16407 \\
\hline Inequality shares in $\%$ & & 59.94 & 29.82 & 6.93 & 3.31 \\
\hline \multicolumn{6}{|l|}{ Group share in $\%$} \\
\hline within & 98.09 & & & & \\
\hline between & 1.91 & - & - & - & - \\
\hline $\mathrm{n}$ & 10,607 & 6,859 & 2,689 & 712 & 347 \\
\hline $\mathrm{N}$ & $61,962,578$ & $40,360,174$ & $15,581,494$ & $4,014,101$ & $2,006,809$ \\
\hline $\mathrm{N}$ in $\%$ & 100.00 & 65.14 & 25.15 & 6.48 & 3.24 \\
\hline
\end{tabular}

Source: German Time Use Survey 2001/02, own calculations.

A closer look on the income distribution is provided by income shares of the poorer and the richer population. The deviations of the decile shares of the different daily working hours ar- 
rangements compared to the average decile shares of all working in percentage points are illustrated in Figure 7; Figure 8 shows the cumulative situation by their Lorenz curves.

Figure 7a

Net income - Decile shares of working (all categories)

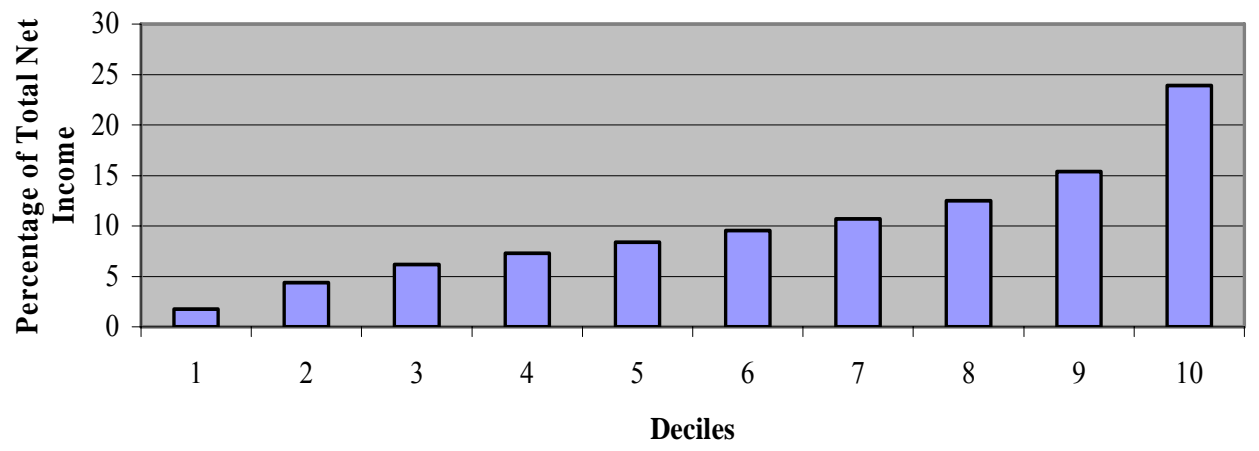

Source: German Time Use Survey 2001/02, own illustration.

Figure $7 \mathbf{b}$

Net income - Deviation of category decile shares compared to the decile shares of working (all categories) in percentage points

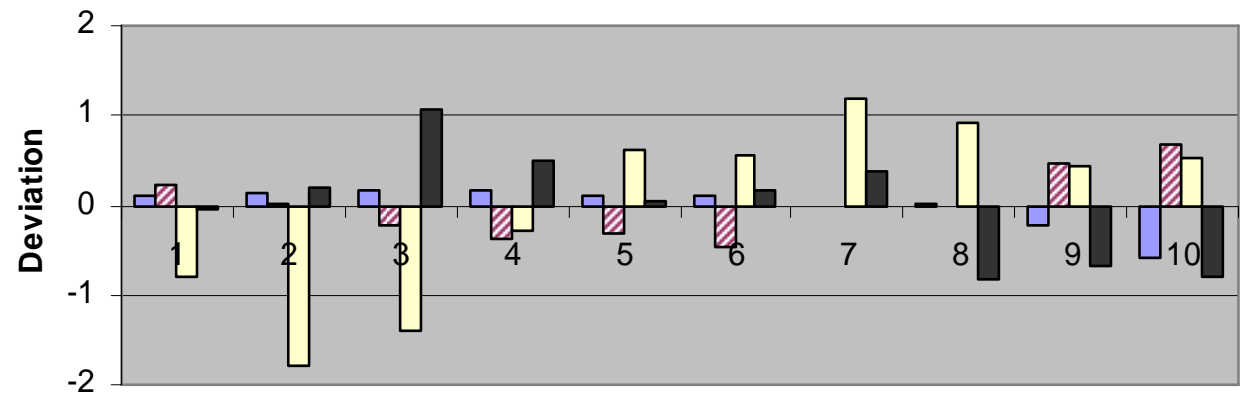

Deciles

$\square$ Cat I $\square$ Cat II $\square$ Cat III $\square$ Cat IV

Note: all figures are due to total decile share limits.

Source: German Time Use Survey 2001/02, own illustration.

One of the decile shares is of particular importance: the 50\% decile share, the well known median. As of Table 2, the lowest income and most unequal distributed category, category III, also has the lowest median: $50 \%$ of those people earn less than $1,252 €$; that is $24 \%$ of the total income of that group.

To characterize the income spread with focus on the poorest and the richest, the $90 / 10$ relation shows the multiple of the richest $10 \%$ income share compared to the income share of the poorest $10 \%$. Again, category III is in particular different to the other categories: the richest $10 \%$ there gain 25 times as much as the poorest $10 \%$. 


\section{Decomposition of inequality}

To answer the question how much of the overall inequality can be 'explained' by the specific groups a decomposition of the overall inequality into inequality within groups and inequality between these groups is required. Such decomposition is available via a class of additively decomposable inequality measures (Shorrocks, 1980, 1984) with

$$
\mathrm{I}_{\text {total }, \mathrm{c}}=\mathrm{I}_{\mathrm{W}}+\mathrm{I}_{\mathrm{B}}=\Sigma_{\mathrm{g}} \mathrm{I}_{\mathrm{Wg}}+\mathrm{I}_{\mathrm{B}}=\Sigma_{\mathrm{g}}\left(\mathrm{n}_{\mathrm{g}} / \mathrm{n}\right)\left(\mu_{\mathrm{g}} / \mu\right)^{\mathrm{c}} \mathrm{I}_{\mathrm{c}}\left(\mathrm{y}_{\mathrm{g}}\right)+\mathrm{I}_{\mathrm{B}}
$$

where $I_{W}$ is within and $I_{B}$ is between group inequality, $g$ is the group index, $\mu$ is the overall respective group mean, $\mathrm{n}$ is the number of observations, $\mathrm{I}_{\mathrm{c}}\left(\mathrm{y}_{\mathrm{g}}\right)$ is the group inequality index dependend on group's incomes $y_{g}$; the group weights $w_{g}=\left(n_{g} / n\right)\left(\mu_{g} / \mu\right)^{c}$ only sums to unity when $\mathrm{c}=0$ or $\mathrm{c}=1$. The only class of inequality measures that satisfies the principle of scale invariance when comparing distributions with different means, and that ensures that the decomposition procedure is valid for arbitrary specifications of the partition, belongs to the generalised entropy class. We use the Theil index decomposition by equations providing additive group specific inequality contributions. Group specific inequality shares (\%) are calculated as a group specific percentage of $\mathrm{I}_{\mathrm{w}}$, the overall within group inequality part. The between group inequality share $(\%)$ is calculated as $I_{B}$ as a percentage of the overall inequality index $I_{\text {total,c. }}$.

Figure 8

Net income - Lorenz curves by category

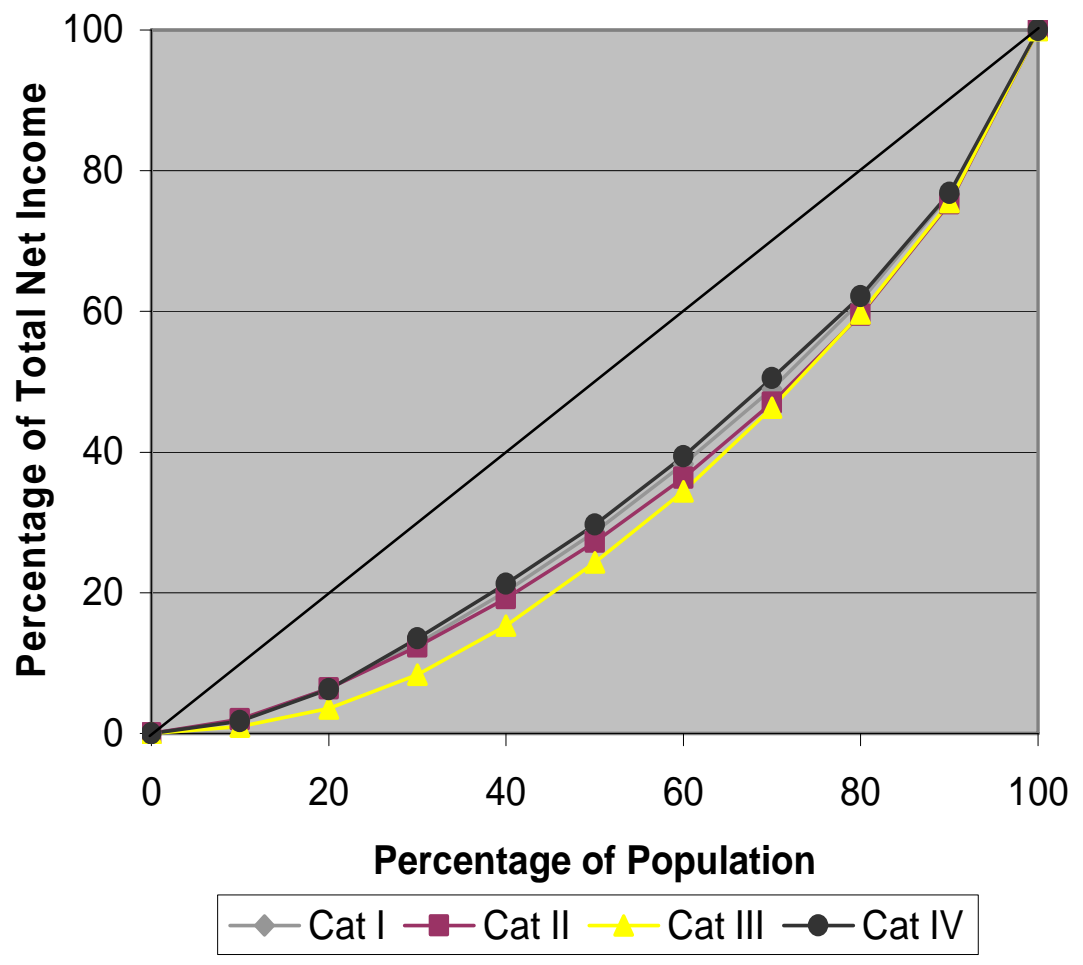

Source: German Time Use Survey 2001/02, own illustration.

The inequality of the most frequent group of category I (normal workday) contributes with a share of $60 \%$ to a large extent to the overall inequality (Table 2). Second in line is the inequality contribution of category II with an inequality share of $30 \%$, whereas the inequality of 
category III adds only $7 \%$ and category IV even only $3 \%$ to the overall inequality. It is remarkable that the between group inequality is only ca. $2 \%$. Thus there is not a big difference between the inequality profiles - but as we have seen in the size of inequality - of our working hours arrangement categories.

\subsection{The distribution of working hours and wages}

To answer the question which income component - hours worked or wage per hour - is responsible for the overall income distribution discussed we separately analyze the distributions of category specific working hours and wages. Note, with regard to hours worked we do not take into account the diary information but the reported weekly working hours, which is adequate to the comparable reported monthly income. ${ }^{15}$ The wage is a calculated net wage per hour and is simply the net monthly personal income divided by weekly working hours times 4.2 .

\section{The distribution of working hours}

There are remarkable differences in the working hours distributions with regard to the specific daily working hours arrangements (see the numeric results in Appendix figures A2-A4 and table A2). So the average working hours in those categories with more than one episode (categories II and IV) amounts to more than 43 hours, while the average weekly working hours in category I is about 38 hours and in category III even only 34 hours per week.

Comparing the distributive measures it is obvious that the categories with those persons working mainly in the non-core period (categories III and IV) have the most unequal distribution of working hours. The Gini coefficient for category III $(0.22893)$ is $60 \%$ higher than the coefficient for the ,normal' working hours arrangement (category I; 0.14342), which has the most equal distribution of all categories. All further distributive measures confirm the result: the non-core/one episode category III with the lowest hours of work shows the most unequal distribution of working hours; an additional aspect of fragmented working conditions.

\section{The distribution of wages}

Are jobs in a non-normal daily working hours arrangement better paid, or characterizes the non-normal working situations bad jobs with lower wages? Does the timing of work and its fragmentation divide the labour market into good and bad jobs?

The answer: though the non-core/one episode category III result in the lowest average wage by $9.17 €$, the non-core/multiple episode category IV - the most irregular working situation result in the highest average wage by $10.18 €$ (see the numeric results in Appendix figures A5A7 and table A3). Thus, the timing of work time and its fragmentation, both, are important to characterize and disentangle the income situation. Remarkably, category III (non-core/one episode) is in both income dimensions the lowest: people there have the lowest wage and the lowest working hours.

15 Further 106 diaries show no information about the weekly working hours and are therefore not taken into account. 
The daily working hours arrangements with the most unequal wage distribution are the categories II and IV (multiple episodes). The differences of the wage Gini coefficients between the daily working hours arrangement with the most unequal wage distribution (category II) and category I - the daily working hours arrangement with the most equal distribution - with a difference of $15 \%$ is, however, essentially smaller than the respective difference of the income distribution.

The wage 90/10 relations between the categories are not as different as the income 90/10 relations between the categories showing the important influence of the hours worked. The wage inequality shares are similar to the shares in the income distribution with the normal workday as the determining (and largest) category of the income inequality profile again.

\subsection{Intermediate summarizing of income distribution results}

A short summary of the above hours and wage results (' + ' indicates an above all over average value, '-' indicates a value below the average) are provided in Table 3. The persons with a fragmented daily working hours arrangement of more than one working episode (categories II and IV) do not just work longer than the average but also have a higher wage than the average resulting in an above-average net income. At the same time these categories have the most unequal wage distribution.

Table 3

Results of the income distribution analysis

\begin{tabular}{|c|c|c|c|c|c|c|c|}
\hline \multirow[b]{2}{*}{ Categories } & \multicolumn{3}{|c|}{ Net income } & \multicolumn{2}{|c|}{ Wage } & \multicolumn{2}{|c|}{$\begin{array}{c}\text { Working } \\
\text { hours }\end{array}$} \\
\hline & I & II III IV & I & II & III IV & I & II III IV \\
\hline Mean & - & +-+ & 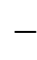 & + & -+ & & +-+ \\
\hline Gini & - & ++- & - & + & -+ & & -++ \\
\hline Atkinson 1 & - & -+- & 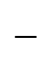 & + & -+ & & -++ \\
\hline Atkinson 2 & - & -++ & & + & -+ & & -++ \\
\hline 90/10 Relation & - & -+- & - & + & -+ & - & -++ \\
\hline
\end{tabular}

Source: German Time Use Survey 2001/02, own calculations.

Non-core work without interruptions results in a below average mean net income. This category III (non-core/one episode) shows the most unequal net income distribution in which also the most unequal working hours distribution is given.

In contrast to this, net income, wage and working hours are relatively equally distributed in category I with a below average net income of all working - the category which includes the persons with 'normal' daily working hours arrangements (core/one episode).

Altogether: The descriptive analyses so far show, that the distribution of income is remarkably influenced by the daily working hours arrangement: not only the timing of work time 
(core vs. non-core) but in particular the fragmentation of the working period (by number of episodes), are determining the income situation and individual economic well-being.

\section{$5 \quad$ Timing and fragmentation of work and earnings - Microeconomic approach and micro- econometric estimates of earnings function}

The following sections quantify an explanatory background of earnings for the different timing and fragmentation daily working hours arrangements. Our model will be based on human capital theory and extended to a market, non-market and social network context. The microeconometric estimates of the respective earnings functions with a treatment effects approach then searches for significant determinants as well as for an overall selection effect ('arrangement treatment effect') with respect to the daily timing of work time and its fragmentation.

\subsection{Theoretical background - Human capital in a market and non-market context}

The human capital approach - theoretically and empirically - has been proven a successful way in applied economics explaining the earnings function. The human capital theory explains earnings in terms of job skills aquired in school and on the job. Based on a life-cycle model, earnings are explained as consequences of individual investment decisions in their skills (Mincer, 1974; Becker, 1975).

The very basic human capital model explains earnings by the following equation,

$$
\ln E_{t}=\ln E_{0}+r_{s} S+a T+b T^{2}
$$

where $E_{t}$ is capacity earnings in year $\mathrm{t}, E_{0}$ is ,original' capacity earnings, $\mathrm{S}$ is years of schooling, $\mathrm{T}$ is years of job experience, $r_{s}$ is the rate of return to schooling and a and $\mathrm{b}$ together describe the rate of return to experience. With observed earnings $\mathrm{Y}$ the typical human capital earnings equation is

$$
\ln Y_{t}=\alpha_{0}+r S+\alpha_{1} T+\alpha_{2} T^{2}
$$

and base for our regression analyses.

The central variable is the rate of return to schooling which approximates the per cent increase in earnings resulting from one extra year of schooling. The parameters $\alpha$ indicate whether the earnings function is concave, where with positive $\alpha_{1}$ and negative $\alpha_{2}$ earnings rise, but at a diminishing rate, peaking at experience level $\mathrm{T}^{*}$ (computable from the slope $\left.\partial \ln Y / \partial t=\alpha_{1}+2 \alpha_{2} T\right)$. 
A simple extension of the earnings function is considered in the following: further market, non-market and social network variables to be tested as important for a more in depth socioeconomic explanation might be comprised in an additional vector $x$ resulting in an extended earnings equation

$$
\ln Y_{t}=\alpha_{0}+r S+\alpha_{1} T+\alpha_{2} T^{2}+x_{i}^{\prime} \beta
$$

This is our general frame further to be estimated; numerous extensions of the basic model are discussed e.g. by Polachek and Siebert (1999).

\subsection{Econometrics - A treatment effects approach for an interdependent es- timation of participation and earnings in different daily working hours arrangement categories}

Within our microeconometric specification we want to disentangle the explanation of the participation in one of the four discussed daily working hours arrangement categories (covering all core/non-core and one/multiple episodes categories) and the category dependent earnings.

One approach could be a multinomial (MNL) estimation of the participation probability and in a second stage in a (MNL) selectivity bias corrected earnings estimate following Lee (1983) generalizing the original two stage Heckman (1979) procedure. This was done by Merz and Burgert (2003b) for their associated study on a two stage working hours approach with daily working hours arrangements based on the 1991/1992 German Time Budget Survey.

In our study at hand, however, we want to quantify the all over impact of a specific daily working hours arrangement category on the category specific earnings equations - by maintaining the detailed explanation of the probability to select a certain category. Thereby the interdependence of the participation and the earnings equation should be respected, because some common explanatory background is presumed for both equations.

An extension of the self-selection problem fits into our modelling concept: it is the measurement of treatment effects and program effectiveness. ${ }^{16}$ Our cross sectional earnings equation of each individual $\mathrm{i}$ for one category $\mathrm{j}(\mathrm{j}=1, \ldots, \mathrm{J} ; \mathrm{J}=4)$ accounts for the endogenous decision to work in that category $\mathrm{j}$

$$
\ln Y_{i j}=\alpha_{0}+r S+\alpha_{1} T+\alpha_{2} T^{2}+x_{i j}^{\prime} \beta_{j}+\delta_{j} C_{i j}+\varepsilon_{i j} \quad(j=1, \ldots, 4),
$$

where $C_{i j}$ is a dummy variable indicating whether or not the individual works in category $\mathrm{j}$. The same principal format has been used in other analyses of programs, experiments, and treatments (Greene, 2003, 787-789). The question is: Does $\delta_{j}$ measure the value and impact of a specific daily working hours arrangement (assuming that the rest of the regression model is correctly specified)? The answer is 'no' if the typical individual who chooses a specific category would have relatively high earnings whether or not an individual chose that cate-

16 Heckman, Lalonde and Smith (1999), Angrist (2001), Angrist and Pischke (2009).

elJ TUR, 2009, Vol. 6, No. 2 
gory. The problem is one of self-selection. If our observation of interdependence is correct, then least squares estimates of $\delta_{j}$ will actually overestimate the treatment effect. The same applies to estimates of the treatment effects in other settings in which the individuals themselves decide whether or not they will receive the treatment.

Our treatment effects model estimates the effect of the endogenous binary decision to participate in a working hours arrangement category $\mathrm{j}$ (treatment) on the continuous earnings variable $Y_{i j}$, conditional on their respective vector of explanatory variables. The binary decision is modelled as the outcome of an unobserved latent variable $C_{i}^{*}$ as:

$$
\begin{aligned}
& C_{i j}^{*}=w_{i j}^{\prime} \gamma_{j}+u_{i j}, \\
& C_{i j}=1 \text { if } C_{i j}^{*}>0,0 \text { otherwise. }
\end{aligned}
$$

Because of the allowed endogenous participation decision, $u_{i j}$ and $\varepsilon_{i j}$ are correlated bivariate normal with mean zero and covariance matrix

$$
\operatorname{cov}\left(u_{i j}, \varepsilon_{i j}\right)=\left(\begin{array}{cc}
\sigma_{j} & \rho_{j} \\
\rho_{j} & 1
\end{array}\right) .
$$

Bringing the two equation model together, the category $\mathrm{j}$ specific earnings function with socio-economic variables and endogenous participation decision is

$$
\begin{aligned}
& E\left[\ln Y_{i j} \mid C_{i j}=1, S_{i j}, T_{i j}, x_{i j}, w_{i j}\right] \\
& \quad=\alpha_{0}+r S+\alpha_{1} T+\alpha_{2} T^{2}+x_{i j}^{\prime} \beta_{j}+\delta_{j} C_{i j}+E\left[\varepsilon_{i j} \mid C_{i j}=1, S_{i j}, T_{i j}, x_{i j}, w_{i j}\right] \\
& \quad=\alpha_{0}+r S+\alpha_{1} T+\alpha_{2} T^{2}+x_{i j}^{\prime} \beta_{j}+\delta_{j} C_{i j}+\rho_{j} \sigma_{\varepsilon j} \lambda_{j}\left(-w_{i j}^{\prime} \gamma\right)
\end{aligned}
$$

The arrangement treatment effect, the selection of a certain daily working hours arrangement, is the difference in expected ln earnings between participants and non participants (Greene, 2003, 788):

$$
E\left[\ln Y_{i j} \mid C_{i j}=1\right]-E\left[\ln Y_{i j} \mid C_{i j}=0\right]=\delta_{j}+\rho_{j} \sigma_{\varepsilon j}\left[\frac{\phi_{i j}}{\Phi_{i j}\left(1-\Phi_{i j}\right)}\right] .
$$

If the selectivity correction $\lambda_{i}$ is omitted from the least squares regression, then this difference is what is estimated by the least squares coefficient on the treatment dummy variable. But since (by assumption) all terms are positive, we see that least squares overestimates the treatment effect.

With a two step estimator - probit for the participation decision and treatment corrected OLS for the earnings equation - we account for the self-selected nature/treatment of a participation in category $\mathrm{j}$ and take into account the correlation of the treatment and the outcome equation with a correct variance covariance matrix of the estimated parameters (STATA: treatreg). Note: this treatment specification is in contrast to other program evaluation approaches where the treatment there is chosen to be independent of the outcome equation. 
One open question remains: How do different categories depend on each other. A Hausman and McFadden (1984) test of the independence of irrelevant alternatives (IIA assumption) here confirms our assumption of the independence of different daily working hours arrangements. ${ }^{17}$ Thus our approach to specify one choice against the universe of all other working categories, with $C_{i j}$ is zero if category $\mathrm{j}$ is not chosen, is strongly supported.

\subsection{Results - Earnings explanation considering timing and fragmentation of daily work}

One major result of our descriptive analysis was, that daily working hours arrangements measured by its daily timing and fragmentation results in category specific income levels as well as income distributions. Thus income and income inequality is influenced by daily working time patterns. The question we want to answer now is, which factors drive these category specific earnings, where earnings are measured by monthly net income of active workers.

Our microeconometric model discussed above - with an interdependent earnings equation by a treatment effects model and a probit equation for the endogenous participation probability for each category - will quantify those factors and show their statistical significance. In addition, the overall category specific influence is quantified and tested for significance.

The substantial hypotheses to be tested are driven by the following strategy:

- Category participation probability: besides human capital and further personal information, the hypotheses and explanatory variables include various concurring non-market time use pattern with personal engagement in given active help for others in the social network, partner's employment, household characteristics, income/wealth situation, receiving help from others in the social network and a general regional indicator (Table 4a).

- Earning' explanatory variables include above all market information: human capital and further socio-economic market oriented factors (occupational status with an explicit consideration of time sovereignty within a self-employment as professions (freelancer, "Freie Berufe", second job indicator, demand side by branches and a regional indicator) (Table $4 b)$.

The particular single results based on the estimation results are discussed now separately for the participation and earnings estimates.

\subsubsection{Explaining participation in daily working hours arrangements}

The explanation of the probability to participate in the respected four daily working hours arrangements - endogenous to the earnings equation - depicted in Table 4a shows a heterogeneous pattern, where at the first glance, the overwhelming significance of the single underlying hypotheses as in the earnings equations is not given anymore. With reference of each working category to the other working individuals only, our coefficients and estimates have

17 Results are available from the authors by request.

elJ TUR, 2009, Vol. 6, No. 2 
nothing to do with the general decision to work or not to work. Consequently, all results have to be interpreted as compared to all alternative working situations.

Personal demographics: Age, as a more or less catch-up variable for the lifecycle situation of a person, is significant only for core jobs; non-core job participation is dependent on other respected factors. Gender differences are visible in a significant manner in the non-core categories with a smaller female probability to participate. On the other hand, the participation probability in a normal workday (category I) is smaller for men, whereas there is no gender difference within a fragmented but core job. To be married is in favour for a normal workday.

Education: There is a clear picture that a higher education is less important for odd jobs at non-core times. For core jobs the participation probability is even significantly lower when education is higher. These results are an important hint to separate the participation decision from the final earnings situation, the way we modelled the working situation.

Non-market time use: Our hypothesis, that non-market time use behaviour has an influence on the choice of the daily working hours arrangement, ${ }^{18}$ is confirmed by significant effects. Time for children seems to be not significant for the choice of a working hours arrangement - a remarkable result - whereas time for household work and time for 'do it yourself'-work is significant, but with a different sign. More time at home in these activities reduces the fragmented core work but increases non-core engagement.

Social networking: With regard to (active) social networking job participation is merely independent of active help for other households.

Partner's employment: The partner's employment activity as a full time or part time worker seems to be of minor importance for the job participation decision. However, for the most irregular case, non-core/multiple episodes, an additional worker effect outside the normal workday situation becomes visible and significant.

Household characteristics: The household context is described by the household size and the existence of young children ( $\leq$ six years, pre-school age). With greater households the participation probability is diminished for normal workdays. Young kids show no influence on the working arrangement decision, a result not expected.

Receiving support in various ways is on the agenda of recent public labour market policy. So far in 2001/2002 receiving help seems to be of no importance for the participation decision between these categories, but might be of importance for the general decision going to work or not.

Income and wealth situation: To analyse the income and wealth situation of the entire household this influence is tested by household net income minus own net income as residual household income and owing the house. The result: Economic opportunities - neither measured by owing the house where the household is living nor by the further available money resources - have an impact on one or the other category decision.

18 Thus a possible simultaneous consideration of paid and non paid working hours here is intentionally disregarded 
Region: Living in East Germany significantly increases the probability to choose a standard daily working hours arrangement with one episode to the burden of a most irregular working pattern of category IV (fragmented non-core jobs).

\subsubsection{Explaining earnings in daily working hours arrangements}

Because of the ln earnings specification the estimated coefficients in Table $4 \mathrm{~b}$ in general approximate the percent increase in earnings resulting from one extra unit of a variable.

First of all: for all categories the specific daily working hours arrangement is highly significant in explaining earnings $\left(\delta_{\mathrm{j}}\right)$. In addition, the selectivity term $\left(\lambda_{\mathrm{j}}\right)$ is highly significant supporting our modelling strategy.

Compared to all other working situations, the multiple episode cases (II and IV) result in significant higher earnings - regardless at core or non-core time - and the most in the core/multiple episode category (Category $j \delta_{j}$ variable). In contrast to this, the one episode working arrangements result in below average income, the lowest for the 'normal' workday (category I). The separate influence of working time and wages are discussed above. Thus, the non-traditional daily working hours arrangements overall show higher earnings, a result, which was not expected when non-normal (in this sense) would be attributed to worse labour market conditions.

Reasons behind this phenomenon are disentangled by the single explanatory factors analyzed now:

Human capital: While work experience with concave character is highly significant for all arrangements, years of schooling (measured in years at school until the German "Abitur") are only important for the non-core segment. Beyond the reference of working individuals in general, this effect might be due to the additional control for the occupational status, which sometimes requires a higher education.

Occupational status: Compared to blue collar workers all other occupational stati in all categories raise earnings. The exemption of being a helping family member might show some support as an additional worker effect but in non-core categories only.

Multiple jobs: As discussed earlier, our data base only allows to add a general dummy for a second job. The very interesting case of an additional job at the specific day under investigation could not be specified. Nevertheless, the result is astonishing: nearly by the same size a second job diminishes earnings in all categories indicating the better earnings situation of one job holders in general.

Demand side: As expected earnings outside agriculture are higher. Though the private and public service sector with the most workers is still growing, a job in the industry results in higher income for all working hour categories.

Region: The general dummy for a job in East Germany is significantly positive for core daily working arrangements and negative for non-core working. The traditional timing of work time therefore results in higher income compared to West Germany. Putting it in other words: 
Joachim Merz, Paul Böhm and Derik Burgert: Timing and fragmentation of work and income inequality

only non-core working conditions are lower paid in East Germany. With regard to the participation decision, East Germans tend to work in a more normal category (I) which in general is lower paid then the fragmented ones.

Table 4a

Timing and fragmentation of work - Endogeneous participation probability estimates by a probit model for daily working hours arrangements

\begin{tabular}{|c|c|c|c|c|}
\hline Participation Probability & $\begin{array}{l}\text { Category I } \\
\text { Core } \\
\text { One episode }\end{array}$ & $\begin{array}{c}\text { Category II } \\
\text { Core } \\
\text { \# episodes } \geq 2\end{array}$ & $\begin{array}{c}\text { Category III } \\
\text { Non-core } \\
\text { One episode }\end{array}$ & $\begin{array}{c}\text { Category IV } \\
\text { Non-core } \\
\# \text { episodes } \geq 2\end{array}$ \\
\hline \multicolumn{5}{|l|}{ Personal demographics } \\
\hline Age & $.0227389 *$ & -.0182999 & -.0220969 & .0306111 \\
\hline Age $^{2}$ & $-.0003184 * *$ & $.0003255 * *$ & .0001241 & -.0003687 \\
\hline Woman & $.1531365 * * *$ & -.0199893 & $-.1680781 * *$ & $-.3783944 * * *$ \\
\hline Married & $.1552043 * *$ & $-.1302822 * *$ & -.0212925 & $-.2004843 *$ \\
\hline \multicolumn{5}{|l|}{ Education } \\
\hline Elemantary & .116942 & -.1358193 & -.1749561 & .254799 \\
\hline Intermediate & .1200956 & -.0870726 & -.1716882 & -.0095316 \\
\hline Spec. upper or upper & $-.0835988 * *$ & $.1385355 * * *$ & $-.2079447 * * *$ & $.1692626 * *$ \\
\hline University & $-.2891626^{* * *}$ & $.330533 * * *$ & -.1448368 & $.2736943 * *$ \\
\hline \multicolumn{5}{|l|}{ Non-market time use } \\
\hline Time for household work & .0000759 & $-.0015483 * * *$ & $.0023518 * * *$ & $.0011799 * * *$ \\
\hline Time for child care & $.0010501 *$ & -.000907 & -.0001078 & -.0011221 \\
\hline Time for do-it-yourself & .000299 & $-.0026076 * * *$ & $.0021689 * * *$ & $.0021063 * *$ \\
\hline \multicolumn{5}{|l|}{ Social networking } \\
\hline Active help (h) & -.0017347 & .0013517 & -.0014825 & $.0048663 *$ \\
\hline \multicolumn{5}{|l|}{ Partner`s employment } \\
\hline partner full time work & -.0763369 & .0253924 & -.0308513 & $.3155059 * * *$ \\
\hline partner part time work & $-.0887075 *$ & .0536556 & .0915853 & .0799004 \\
\hline \multicolumn{5}{|l|}{ Household characteristics } \\
\hline Receiving help (h) & .0007053 & -.0020338 & .0010574 & .0014867 \\
\hline Number of hh members & $-.0652222 * * *$ & $.0669324 * * *$ & .0017645 & .018666 \\
\hline Young kids & -.0634876 & .0857412 & -.0448537 & .0361543 \\
\hline \multicolumn{5}{|l|}{ Income/wealth situation } \\
\hline Own house & -.0602891 & $.0840075 *$ & -.0599845 & .049606 \\
\hline Residual income & $8.92 \mathrm{e}-06$ & $-5.52 e-06$ & $-6.23 e-06$ & $-1.45 e-06$ \\
\hline \multicolumn{5}{|l|}{ Region } \\
\hline East Germany & $.2765265 * * *$ & $-.2670162 * * *$ & .014006 & $-.2985634 * * *$ \\
\hline Constant & .0018567 & -.4213718 & $-.7616166^{*}$ & $-2.777401 * * *$ \\
\hline Wald chi ${ }^{2}(16)$ & 1386.03 & 2525.95 & 4938.93 & 6425.18 \\
\hline $\mathrm{p}$-value for $\mathrm{chi}^{2}$ & $.00000 * * *$ & $.00000 * * *$ & $.00000 * * *$ & $.00000 * * *$ \\
\hline n (working: 10,607) & 6852 & 2678 & 719 & 358 \\
\hline
\end{tabular}

Significance levels: * 5\%,**1\%,*** $0.1 \%$

Source: German Time Budget Survey 2001/2002, own calculations. 
Joachim Merz, Paul Böhm and Derik Burgert: Timing and fragmentation of work and income inequality

Table 4b

Earnings and timing and fragmentation of work Earnings estimates by a treatment effects model

\begin{tabular}{|c|c|c|c|c|}
\hline In(earnings) & $\begin{array}{c}\text { Category I } \\
\text { Core } \\
\text { One episode }\end{array}$ & $\begin{array}{c}\text { Category II } \\
\text { Core } \\
\text { \# episodes } \geq 2\end{array}$ & $\begin{array}{c}\text { Category III } \\
\text { Non-core } \\
\text { One episode }\end{array}$ & $\begin{array}{c}\text { Category IV } \\
\text { Non-core } \\
\text { \# episodes } \geq 2\end{array}$ \\
\hline Category j $\delta_{j}$ & $-3.908531 * * *$ & $2.850709 * * *$ & $-2.217199 * * *$ & $1.57194 * * *$ \\
\hline Hazard lambda & $2.362135 * * *$ & $-1.636485 * * *$ & $1.035406 * * *$ & $-.6644788 * * *$ \\
\hline \multicolumn{5}{|l|}{ Human capital } \\
\hline School years (S) & .0052858 & .0004131 & $.0429798 * * *$ & $.0545976 * * *$ \\
\hline Work experience (T) & $.0578081 * * *$ & $.05921 * * *$ & $.0444624 * * *$ & $.0419555 * * *$ \\
\hline Work experience ${ }^{2}\left(\mathrm{~T}^{2}\right)$ & $-.0010511 * * *$ & $-.001103 * * *$ & $-.0007361 * * *$ & $-.0006443 * * *$ \\
\hline \multicolumn{5}{|l|}{ Occupational status } \\
\hline Reference: blue collar & - & - & - & - \\
\hline Self-employed 0 empl. & $.5877811 * * *$ & $.5590384 * * *$ & $.7731187 * * *$ & $.8196024 * * *$ \\
\hline Self-employed $>0$ empl.. & $.385388 *$ & $.3715193 * *$ & $.6535276 * * *$ & $.7175627 * * *$ \\
\hline Liberal professions & $.4569893 * * *$ & $.4563182 * * *$ & $.5722316 * * *$ & $.6073045 * * *$ \\
\hline Civil servants & $.8885734 * * *$ & $.8803991 * * *$ & $.9466153 * * *$ & $.9849433 * * *$ \\
\hline White collar worker & $.4029769 * * *$ & $.3505992 * * *$ & $.3148965 * * *$ & $.3512981 * * *$ \\
\hline Apprentice & $-.3574205 * * *$ & $-.3627674 * * *$ & $-.3195913 * * *$ & $-.2942108 * * *$ \\
\hline Helping family member & -.1604767 & -.1234818 & $-.2040246^{* * *}$ & $-.2584336^{*}$ \\
\hline \multicolumn{5}{|l|}{ Multiple jobs } \\
\hline Second job & $-.2356443 * * *$ & $-.2275196 * * *$ & $-.2438255 * * *$ & $-.263097 * * *$ \\
\hline \multicolumn{5}{|l|}{ Demand side } \\
\hline \multicolumn{5}{|l|}{ Ref.: agriculture } \\
\hline Industry & $.6705779 * * *$ & $.6928089 * * *$ & $.7440246 * * *$ & $.7576406 * * *$ \\
\hline Services & $.4377631 * * *$ & $.430295 * * *$ & $.447006^{* * *}$ & $.4520374 * * *$ \\
\hline \multicolumn{5}{|l|}{ Region } \\
\hline Ost & $.1744386^{* *}$ & .0219009 & $-.2191925 * * *$ & $-.1931014 * * *$ \\
\hline Constant & $8.200124 * * *$ & $5.066563 * * *$ & $5.595438 * * *$ & $5.228578 * * *$ \\
\hline Wald $\operatorname{chi}^{2}(16)$ & 1386.03 & 2525.95 & 4938.93 & 6425.18 \\
\hline $\mathrm{p}$-value for $\mathrm{chi}^{2}$ & $.00000 * * *$ & $.00000 * * *$ & $.00000 * * *$ & $.00000 * * *$ \\
\hline n (working: 10607) & 6852 & 2678 & 719 & 358 \\
\hline
\end{tabular}

Significance levels: * 5\%, ** 1\%,*** $0.1 \%$.

Source: German Time Budget Survey 2001/2002, own calculations.

To summarize: in addition to the significance of human capital, occupational status, the multiple job situation as well as demand side and all over regional factors timing of work plays a significant role in explaining individual earnings. The pattern is different in different daily working hours arrangements. Every working hours arrangement category results in significantly different earnings supporting our modelling strategy. 
Joachim Merz, Paul Böhm and Derik Burgert: Timing and fragmentation of work and income inequality

\subsubsection{Summarizing the results of earnings explanation considering timing and fragmentation of daily work}

To summarize our results an overview of explanatory factors of earnings considering timing and fragmentation of daily work is given in Table 5.

Table 5

Earnings explanation considering timing and fragmentation of daily work An overview of explanatory pattern

\begin{tabular}{|c|c|c|c|c|c|c|c|c|}
\hline & \multicolumn{2}{|c|}{$\begin{array}{l}\text { Category I } \\
\text { Core } \\
\text { One episode }\end{array}$} & \multicolumn{2}{|c|}{$\begin{array}{c}\text { Category II } \\
\text { Core } \\
\text { \# episodes } \geq 2\end{array}$} & \multicolumn{2}{|c|}{$\begin{array}{l}\text { Category III } \\
\text { Non-core } \\
\text { One episode }\end{array}$} & \multicolumn{2}{|c|}{$\begin{array}{c}\text { Category IV } \\
\text { Non-core } \\
\# \text { episodes } \geq 2\end{array}$} \\
\hline & earnings & part. & earnings & part. & earnings & part. & earnings & part. \\
\hline Category $\mathrm{j}$ & --- & & +++ & & --- & & +++ & \\
\hline$\lambda$ & +++ & & --- & & +++ & & --- & \\
\hline \multicolumn{9}{|l|}{ Personal characteristics } \\
\hline Demographics & & +++ & & -- & & - & & -- \\
\hline Human capital & +++ & & +++ & & +++ & & +++ & \\
\hline Education & & --- & & +++ & & -- & & ++ \\
\hline Occupational status & +++ & & +++ & & +++ & & +++ & \\
\hline Multiple jobs & --- & & --- & & --- & & --- & \\
\hline Non-market time use & & & & --- & & +++ & & +++ \\
\hline $\begin{array}{l}\text { Demand side: } \\
\text { business sectors }\end{array}$ & +++ & & +++ & & +++ & & +++ & \\
\hline Social networking & & 0 & & 0 & & 0 & & + \\
\hline \multicolumn{9}{|l|}{ Partner's characteristics } \\
\hline Partner`s employment & & - & & 0 & & 0 & & +++ \\
\hline \multicolumn{9}{|l|}{ Household characteristics } \\
\hline $\begin{array}{l}\text { Household } \\
\text { characteristics }\end{array}$ & & --- & & +++ & & 0 & & 0 \\
\hline $\begin{array}{l}\text { Income/wealth } \\
\text { situation }\end{array}$ & & 0 & & + & & 0 & & 0 \\
\hline \multicolumn{9}{|l|}{ Regional variables } \\
\hline $\begin{array}{l}\text { Region (East Ger- } \\
\text { many) }\end{array}$ & ++ & +++ & 0 & --- & --- & & --- & --- \\
\hline
\end{tabular}

blank field: not specified, 0 not significant, significance levels: $* 5 \%, * * 1 \%, * * * 0.1 \%$ marked by respective coefficients signs .

Source: German Time Budget Survey 2001/2002, own calculations.

Interpreting the stylized results of Table 5 we can conclude with the overall hypothesis: The driving factors of so-called 'normal' and ,non-normal' workdays are quite different: the timing of work time as well as the fragmentation of daily work are significant factors in explaining individual earnings. 
The results support our modelling and the two stage explanation in particular: the probability to participate to a certain daily working hours arrangement shows a different explanatory pattern than the final earnings as the economic result. This is in line with the findings of Merz and Burgert (2003a) for category specific hours of work.

The participation probability of a specific daily working hours arrangement - given working shows different explanatory pattern for different arrangements. Demographics, education, non-market time use, partner and household characteristics as well as regional variables are important but of different influence in explaining working hours in different daily working hours arrangements.

The earnings function specification results in highly significant - but in size and sign different - coefficients for all variables included, showing the importance of human capital, occupational status, multiple job and demand side factors by business sectors and regional influences.

\section{Concluding remarks}

Our study is adding insights into economic well-being and working hours arrangements with particular daily work effort characteristics and its resulting income distribution. The work effort characteristics we regard are about labour market flexibility with focus on the daily timing of work and its fragmentation, and its consequences on income inequality. The main result: the timing and fragmentation of daily work is significant for the resulting earnings. Fragmented working hours arrangements compared to a continuous daily working schedule yield higher incomes and has distributional consequences which is shown by the descriptive and econometric results.

\section{Descriptive and distributional results}

On average: Persons in daily working hours arrangements with more than one working episode (fragmentation, categories II and IV) work longer, have a higher wage rate and thus an above-average income.

Distribution: All non-normal daily working hours arrangements (categories II,III,IV) compared to the normal situation (category I) show higher inequalities with regard to hours worked, wage paid, and income achieved; one exception: the most irregular daily working hours arrangement (category IV) has the most equally distributed income.

Non-core work without interruptions results in a below average wage and mean net income. This category (III, non-core/one episode), consisting of typical part time jobs as well as of less paid jobs, delivers the most unequal net income distribution in which also the most unequal working hours distribution is given.

Thus, the non-normal, atypical working schedules as regarded here result in higher as well lower mean net income. Whereas fragmented work yields above mean income (regardless 
core respective non-core work), not interrupted non-core work not only yields a below average but also a highly unequally distributed net income.

The descriptive and distributive analysis thus has shown that the timing and fragmentation of work time do have distinct consequences on the earnings situation and its distribution; atypical work is indeed heterogeneous, it offers a higher income opportunity as well as a precarious job situation.

\section{Microeconometric results}

The estimates with endogenous self-selection (treatment effects approach) explaining earnings and participation (MNL-approach) in different daily working hours arrangements support our interdependent two stage modelling strategy with the overall result:

Individual earnings in Germany are dependent on and significantly different with regard to the daily working hours arrangement capturing timing and fragmentation of work.

The participation probability for the core/non-core and number of episodes working time categories follow different explanatory pattern with regard to personal characteristics (demographics, human capital, education, occupational status, multiple jobs, non-market time use) demand side (business sectors), partner's (employment) and household characteristics (composition, wealth) as well as a regional indicator. Whereas active help has some influence on choosing a fragmented/non-core arrangement, getting support, however, seems not to play a role for that decision. Thus, social networking - in contrast to some expectations - has only a small impact on paid working schedules.

The mentioned market and non-market factors also are important and significant in explaining earnings - and thus the income distribution in all daily working hours arrangements, however, in a different pattern. A simple overall explanation of the participation and the earnings situation cannot be deducted: the heterogeneity of atypical work schedules mirrors in the heterogeneity of the individuals behind. However, our detailed findings support targeted modern economic and social policy, which has to respect the individual situation when non-traditional labour market situations and flexibility impacts are regarded.

Since our attempt to analyse the timing and fragmentation of daily working hours has shown to be important as working schedules itself and for its impact on income and the income distribution, further research on the growing importance of the broad range of atypical working schemes will miss important factors if fragmentation and the timing of work time would not be considered. 


\section{Appendix}

Table A1

Number of persons in \% by category and different break definition

\begin{tabular}{lrrrrrrrrrrr}
\hline & \multicolumn{3}{c}{$\begin{array}{c}\text { Duration of } \\
\text { break } \geq \mathbf{3 0} \text { minutes }\end{array}$} & \multicolumn{3}{c}{$\begin{array}{c}\text { Duration of } \\
\text { break } \geq \mathbf{6 0} \text { minutes }\end{array}$} & \multicolumn{3}{c}{$\begin{array}{c}\text { Duration of } \\
\text { break } \geq \mathbf{9 0} \text { minutes }\end{array}$} \\
& $\mathrm{N}$ in \% & $\mathrm{N}$ & $\mathrm{n}$ & $\mathrm{N}$ in \% & $\mathrm{N}$ & $\mathrm{n}$ & $\mathrm{N}$ in \% & $\mathrm{N}$ & $\mathrm{n}$ \\
\hline Category I & 27.4 & $17,031,821$ & 3,429 & 65.1 & $40,503,406$ & 6,884 & 78.1 & $48,552,582$ & 8,055 \\
Category II & 62.9 & $39,102,162$ & 6,154 & 25.1 & $15,605,547$ & 2,698 & 12.2 & $7,560,907$ & 1,525 \\
Category III & 4.9 & $3,073,410$ & 588 & 6.5 & $4,037,688$ & 716 & 6.7 & $4,157,613$ & 743 \\
Category IV & 4.8 & $2,965,380$ & 477 & 3.3 & $2,026,132$ & 350 & 3.1 & $1,901,671$ & 325 \\
All categories & 100 & $62,172,772$ & 10,648 & 100 & $62,172,772$ & 10,648 & 100 & $62,172,772$ & 10,648 \\
\hline
\end{tabular}

Source: German Time Use Survey 2001/02, own calculations.

Table A2

Time spent for work, breaks, non work by category per day

\begin{tabular}{|c|c|c|c|c|}
\hline & $\begin{array}{l}\text { Category I } \\
\text { Core } \\
\text { one episode }\end{array}$ & $\begin{array}{c}\text { Category II } \\
\text { Core } \\
\text { multiple episodes }\end{array}$ & $\begin{array}{c}\text { Category III } \\
\text { Non-core } \\
\text { one episode }\end{array}$ & $\begin{array}{c}\text { Category IV } \\
\text { Non-core } \\
\text { multiple episodes }\end{array}$ \\
\hline $\mathrm{N}$ & $40,503,406$ & $15,605,547$ & $4,037,688$ & $2,026,132$ \\
\hline $\mathrm{n}$ & 6,884 & 2,698 & 716 & 350 \\
\hline Average time spent for work & 7’40’' & 7’22’’ & $5^{\prime} 24^{\prime \prime}$ & 7'31', \\
\hline Average time spent for breaks & --- & 2’23’’ & --- & $10^{\prime} 22^{\prime \prime}$ \\
\hline Average time spent for non-work & $16{ }^{\prime} 20^{\prime}$, & $14^{\prime} 15^{\prime}$, & $18^{\prime} 36^{\prime}$, & 6’07', \\
\hline
\end{tabular}

Source: German Time Use Survey 2001/02, own calculations. 
Figure A1

No. of persons by activity and day time - Category IV (non-core/multiple episodes) excluding night-workers.

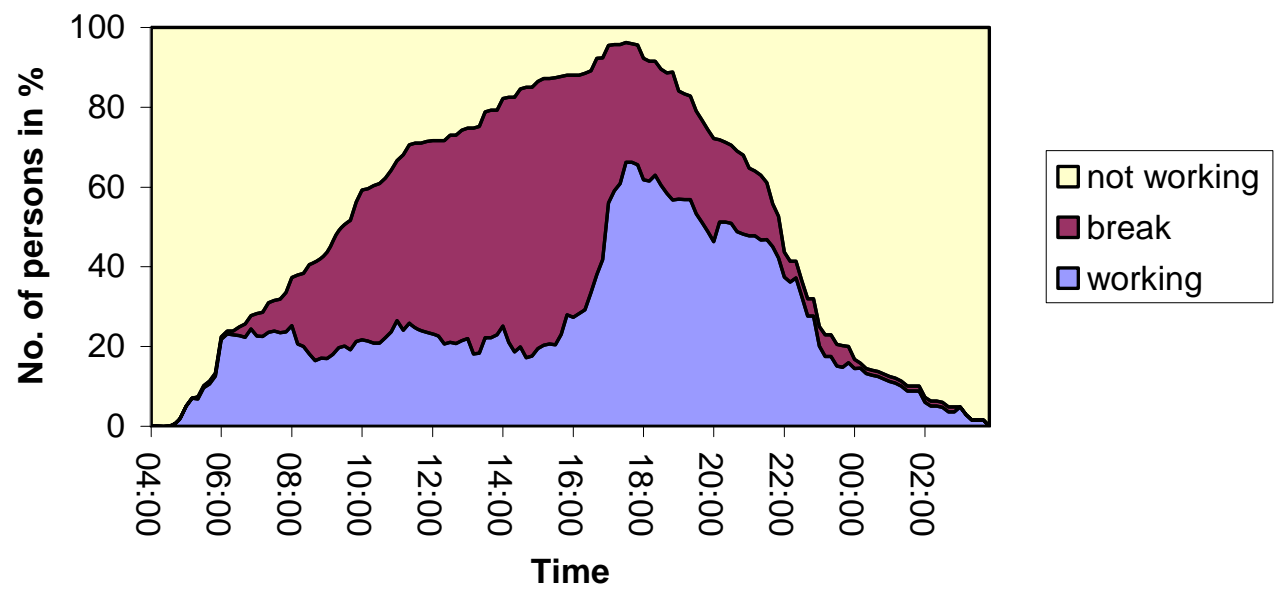

Source: German Time Use Survey 2001/02, own illustration.

Figure A2

Working hours - Lorenz curves by category

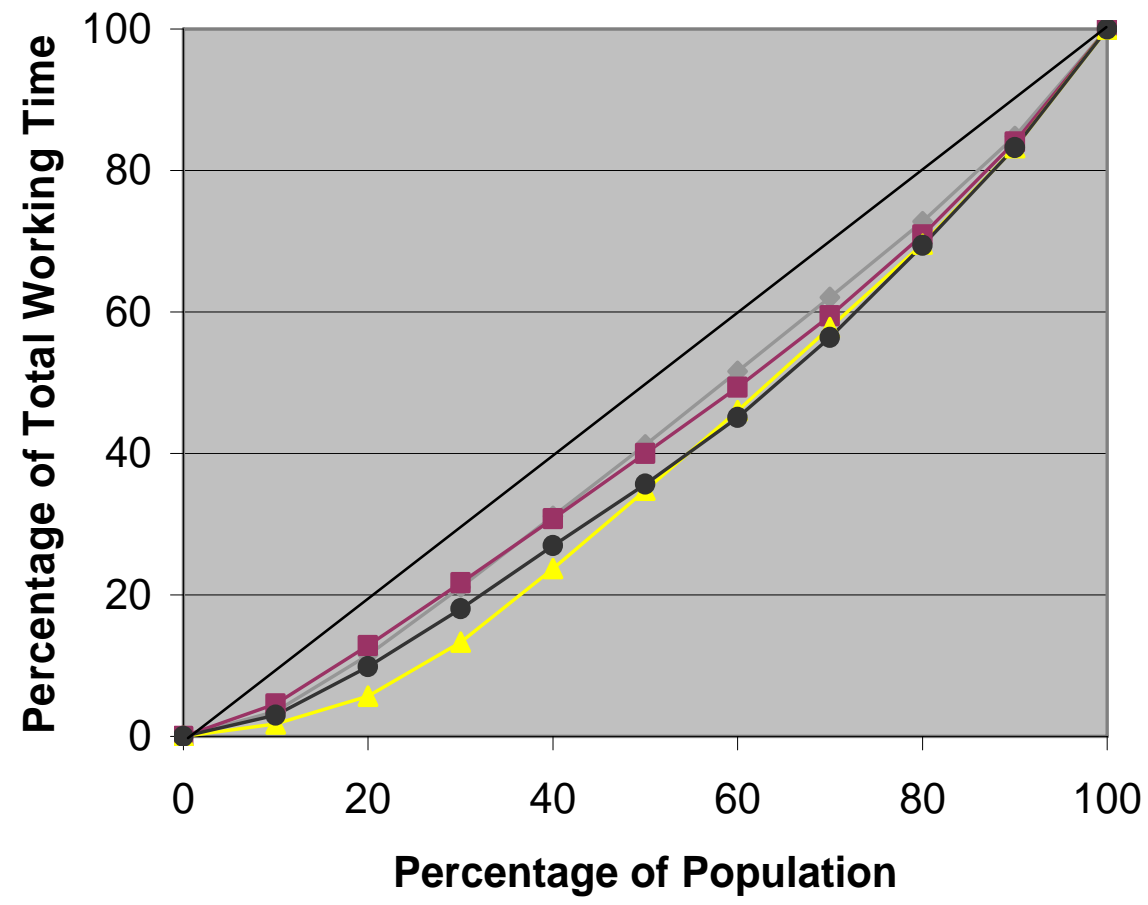

\section{$\rightarrow$ Cat I $\rightarrow$ Cat II $\triangle$ Cat III $\rightarrow$ Cat IV}

Source: German Time Use Survey 2001/02, own illustration. 
Figure A3

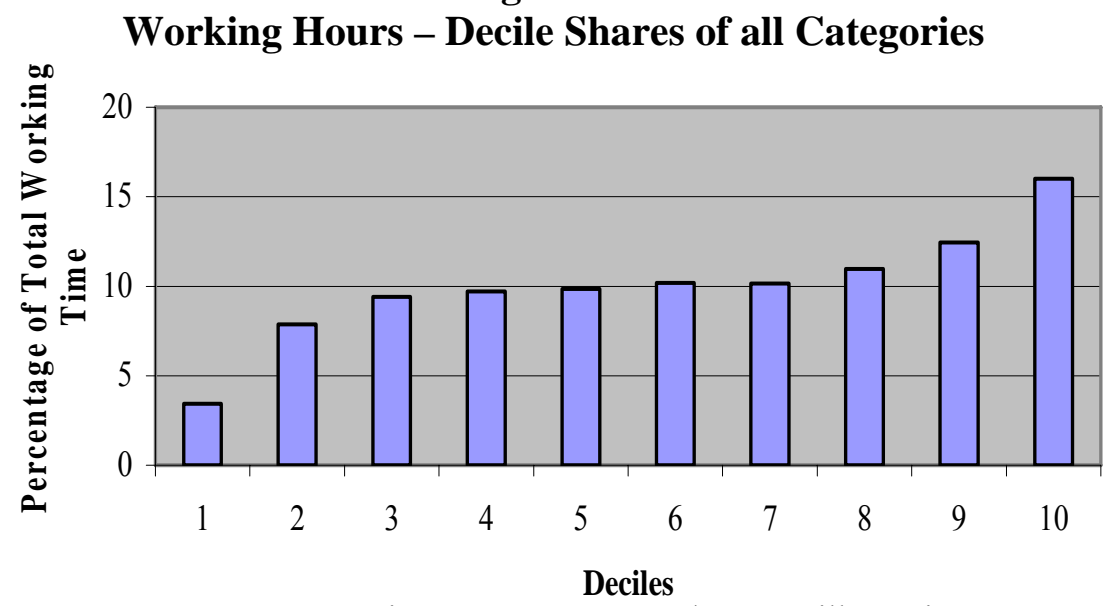

Source: German Time Use Survey 2001/02, own illustration.

Figure A4

Working hours - Deviation of decile shares compared to the decile shares of all categories in percentage points

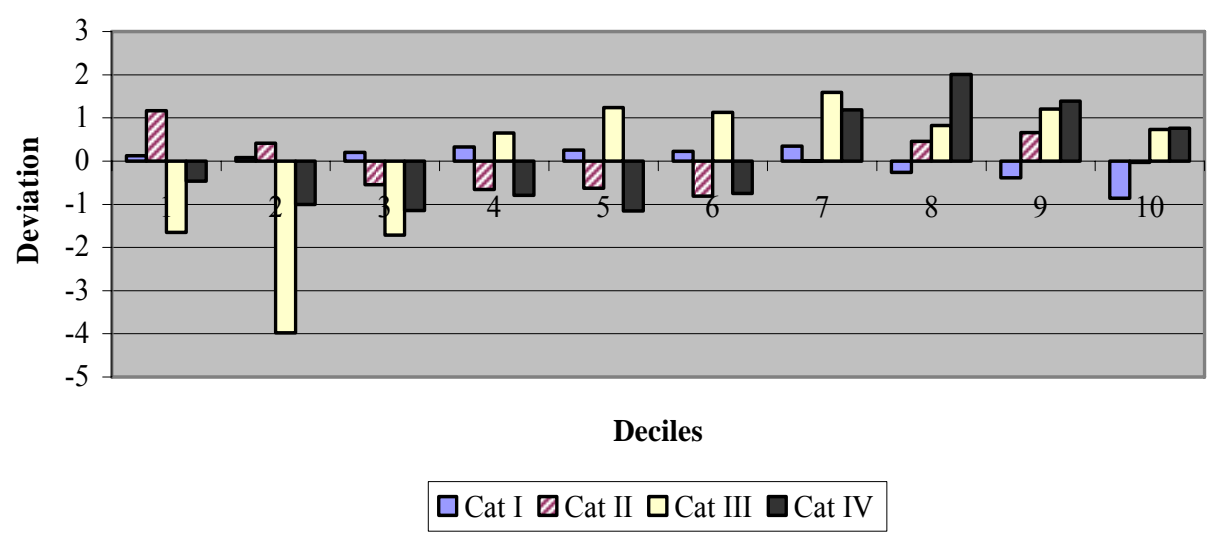

Source: German Time Use Survey 2001/02, own illustration. 
Figure A5

Wage - Lorenz curves by category

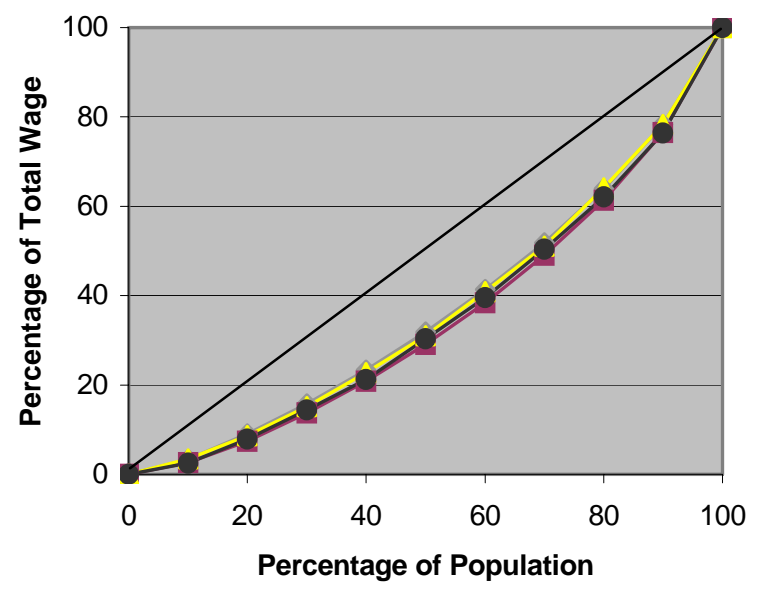

$\longrightarrow$ Cat I - Cat II - Cat III $\multimap$ Cat IV

Source: German Time Use Survey 2001/02, own illustration.

Figure A6

Wage - Decile shares of all categories

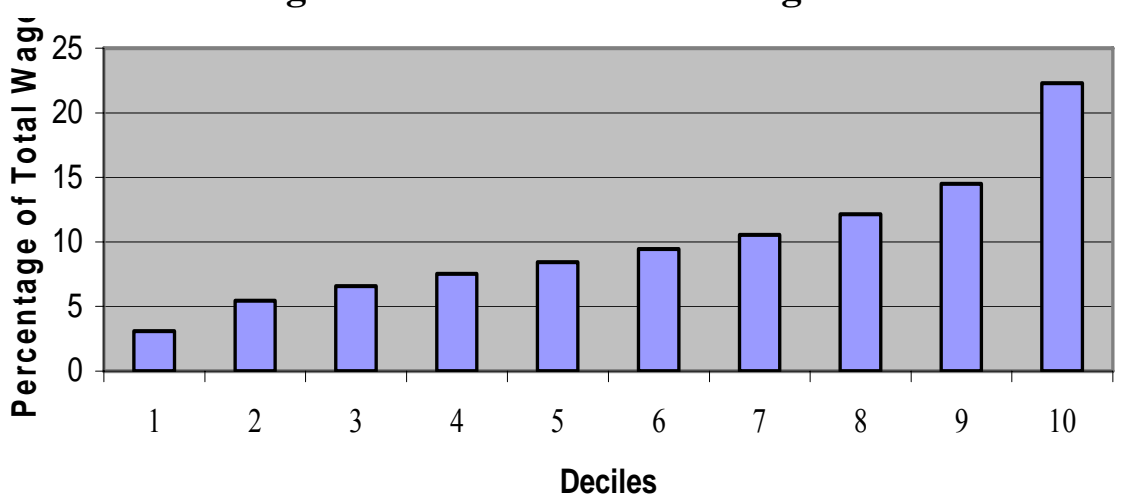

Source: German Time Use Survey 2001/02, own illustration. 
Joachim Merz, Paul Böhm and Derik Burgert: Timing and fragmentation of work and income inequality

Table A3

Working hours - Distributive measures by category

\begin{tabular}{|c|c|c|c|c|c|}
\hline & Total & $\begin{array}{c}\text { Category I } \\
\text { (core/ } \\
\text { episode) }\end{array}$ & $\begin{array}{c}\text { Category II } \\
(\text { core/ } \\
\text { \#episodes }>1)\end{array}$ & $\begin{array}{c}\text { Category } \\
\text { (non-core/ } \\
\text { one episode) }\end{array}$ & $\begin{array}{c}\text { Category IV } \\
\text { (non-core/ } \\
\text { \#episodes }>1 \text { ) }\end{array}$ \\
\hline Mean in $\mathrm{h}$ & 39.41 & 38.18 & 43.35 & 34.02 & 44.21 \\
\hline Median in $\mathrm{h}$ & 40.00 & 39.00 & 40.00 & 38.50 & 40.00 \\
\hline Kurtosis & 2.74 & 2.86 & 1.42 & 0.70 & 0.98 \\
\hline Variation coefficient & 0.32 & 0.29 & 2.51 & 0.43 & 0.37 \\
\hline \multicolumn{6}{|l|}{ Distributive measures } \\
\hline Gini coefficient & 0.15778 & 0.14342 & 0.15543 & 0.22893 & 0.20019 \\
\hline \multicolumn{6}{|l|}{ Atkinson-Index } \\
\hline$\varepsilon=1$ & 0.07333 & 0.06777 & 0.05496 & 0.15147 & 0.09496 \\
\hline$\varepsilon=2$ & 0.23033 & 0.21972 & 0.14713 & 0.42123 & 0.28201 \\
\hline \multicolumn{6}{|l|}{$\begin{array}{l}\text { Decile shares in \% } \\
\text { (Decile limits in h) }\end{array}$} \\
\hline 1st decile & $3.44(22.0)$ & $3.56(22.0)$ & $4.6(32.0)$ & $1.79(10.0)$ & $2.97(23.0)$ \\
\hline 2rd decile & $7.86(35.0)$ & $7.94(35.0)$ & $8.27(38.0)$ & $3.88(20.0)$ & $6.85(35.0)$ \\
\hline 3rd decile & $9.39(38.0)$ & $9.59(38.0)$ & $8.84(38.5)$ & $7.68(35.0)$ & $8.24(38.0)$ \\
\hline 4th decile & $9.71(38.5)$ & $10.03(38.5)$ & $9.05(40.0)$ & $10.36(36.0)$ & $8.92(40.0)$ \\
\hline 5th decile & $9.84(40.0)$ & $10.09(39.0)$ & $9.21(40.0)$ & $11.08(38.5)$ & $8.68(40.0)$ \\
\hline 6th decile & $10.17(40.0)$ & $10.39(40.0)$ & $9.36(42.0)$ & $11.29(40.0)$ & $9.42(45.0)$ \\
\hline 7th decile & $10.14(41.0)$ & $10.48(40.0)$ & $10.15(46.5)$ & $11.73(40.0)$ & $11.33(52.5)$ \\
\hline 8th decile & $10.97(45.0)$ & $10.71(43.0)$ & $11.43(51.0)$ & $11.79(42.0)$ & $12.98(60.0)$ \\
\hline 9th decile & $12.45(55.0)$ & $12.06(50.0)$ & $13.11(60.0)$ & $13.66(50.0)$ & $13.84(64.0)$ \\
\hline 10th decile & 16.01 & 15.15 & 15.98 & 16.74 & 16.77 \\
\hline 90/10 Relation & 4.65 & 4.26 & 3.47 & 9.35 & 5.65 \\
\hline \multicolumn{6}{|l|}{ Decomposition } \\
\hline Theil Index & 0.05608 & 0.05011 & 0.04746 & 0.11097 & 0.07504 \\
\hline Inequality shares in $\%$ & & 58.94 & 24.45 & 11.48 & 5.13 \\
\hline \multicolumn{6}{|l|}{ Group share in \%: } \\
\hline within & 95.72 & & & & \\
\hline between & 4.28 & & & & \\
\hline $\mathrm{n}$ & 10,501 & 6,788 & 2,662 & 704 & 347 \\
\hline $\mathrm{N}$ & $61,362,471$ & $39,982,330$ & $15,425,900$ & $3,947,433$ & $2,006,809$ \\
\hline $\mathrm{N}$ in $\%$ & 100.00 & 65.16 & 25.14 & 6.43 & 3.27 \\
\hline
\end{tabular}

Source: German Time Use Survey 2001/02, own calculations. 
Figure A7

Wage - Deviation of decile shares compared to the decile shares of all categories in percentage points

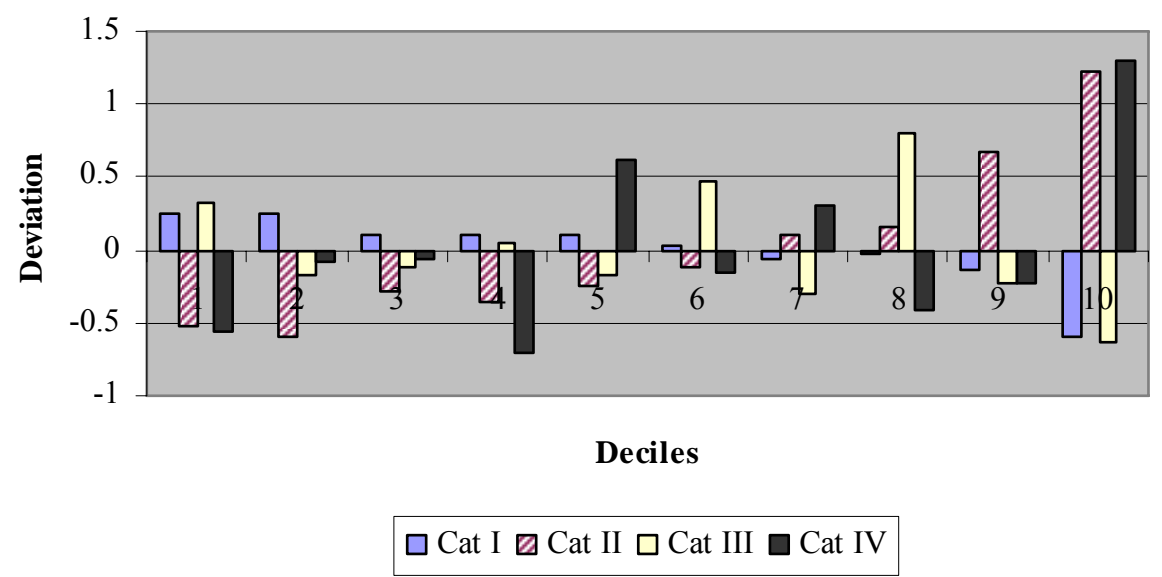

Source: German Time Use Survey 2001/02, own illustration. 
Table A4

Wage - Distributive measures by category

\begin{tabular}{|c|c|c|c|c|c|}
\hline & Total & $\begin{array}{c}\text { Category I } \\
\text { (core/ } \\
\text { episode) }\end{array}$ & $\begin{array}{c}\text { Category II } \\
\quad \text { core/ } \\
\text { \#episodes }>1)\end{array}$ & $\begin{array}{c}\text { Category III } \\
\text { (non-core/ } \\
\text { one episode) }\end{array}$ & $\begin{array}{c}\text { Category IV } \\
\text { (non-core/ } \\
\text { \#episodes }>1 \text { ) }\end{array}$ \\
\hline Mean in $€$ & 9.79 & 9.71 & 10.10 & 9.17 & 10.18 \\
\hline Median in $€$ & 8.66 & 8.63 & 8.92 & 8.23 & 8.62 \\
\hline Scewness & 3.00 & 3.63 & 1.92 & 2.75 & 1.99 \\
\hline Kurtosis & 21.56 & 31.56 & 6.48 & 18.96 & 6.24 \\
\hline Variation coefficient & 0.58 & 0.56 & 0.61 & 0.54 & 0.58 \\
\hline \multicolumn{6}{|l|}{ Distributive measures } \\
\hline Gini Coefficient & 0.27981 & 0.26783 & 0.30785 & 0.27126 & 0.29128 \\
\hline \multicolumn{6}{|l|}{ Atkinson-Index } \\
\hline$\varepsilon=1$ & 0.13375 & 0.12299 & 0.16215 & 0.11799 & 0.14747 \\
\hline$\varepsilon=2$ & 0.29146 & 0.26517 & 0.35994 & 0.22803 & 0.34271 \\
\hline \multicolumn{6}{|l|}{$\begin{array}{l}\text { Decile shares in \% } \\
\text { (Decile limits in } € \text { ) }\end{array}$} \\
\hline 1st decile & $3.09(4.46)$ & $3.34(4.82)$ & $2.56(4.06)$ & $3.42(4.12)$ & $2.54(4.17)$ \\
\hline 2rd decile & $5.44(5.95)$ & $5.69(6.09)$ & $4.85(5.80)$ & $5.26(5.41)$ & $5.35(6.09)$ \\
\hline 3rd decile & $6.58(6.94)$ & $6.69(6.96)$ & $6.29(6.94)$ & $6.46(6.45)$ & $6.52(7.37)$ \\
\hline 4th decile & $7.53(7.81)$ & $7.64(7.85)$ & $7.17(7.78)$ & $7.57 \quad(7.3)$ & $6.82(7.97)$ \\
\hline 5th decile & $8.43(8.66)$ & $8.54(8.63)$ & $8.18(8.96)$ & $8.26(8.22)$ & $9.05(8.62)$ \\
\hline 6th decile & $9.43(9.74)$ & $9.46(9.67)$ & $9.31(10.05)$ & $9.90(9.67)$ & $9.28(10.03)$ \\
\hline 7th decile & $10.54(11.05)$ & $10.48(10.86)$ & $10.65(11.45)$ & $10.23(10.42)$ & $10.85(11.75)$ \\
\hline 8th decile & $12.15(12.90)$ & $12.12(12.76)$ & $12.31(13.54)$ & $12.96(11.91)$ & $11.73(12.99)$ \\
\hline 9th decile & $14.51(16.13)$ & $14.37(15.76)$ & $15.18(17.93)$ & $14.29(14.78)$ & $14.28(15.81)$ \\
\hline 10th decile & 22.28 & 21.68 & 23.51 & 21.65 & 23.58 \\
\hline 90/10 Relation & 7.21 & 6.49 & 9.18 & 6.33 & 9.28 \\
\hline \multicolumn{6}{|l|}{ Decomposition } \\
\hline Theil Index & 0.1375 & 0.12803 & 0.16145 & 0.12499 & 0.14783 \\
\hline Inequality shares in \% & & 60.32 & 30.53 & 5.49 & 3.66 \\
\hline $\begin{array}{l}\text { Group share in \%: } \\
\text { Within }\end{array}$ & 99.78 & & & & \\
\hline Between & 0.22 & & & & \\
\hline $\mathrm{n}$ & 10,501 & 6,788 & 2,662 & 704 & 347 \\
\hline $\mathrm{N}$ & $61,362,471$ & $39,982,330$ & $15,425,900$ & $3,947,433$ & $2,006,809$ \\
\hline $\mathrm{N}$ in $\%$ & 100.00 & 65.16 & 25.14 & 6.43 & 3.27 \\
\hline
\end{tabular}

Source: German Time Use Survey 2001/02, own calculations. 
Figure A8

\section{Gini coefficients by category}

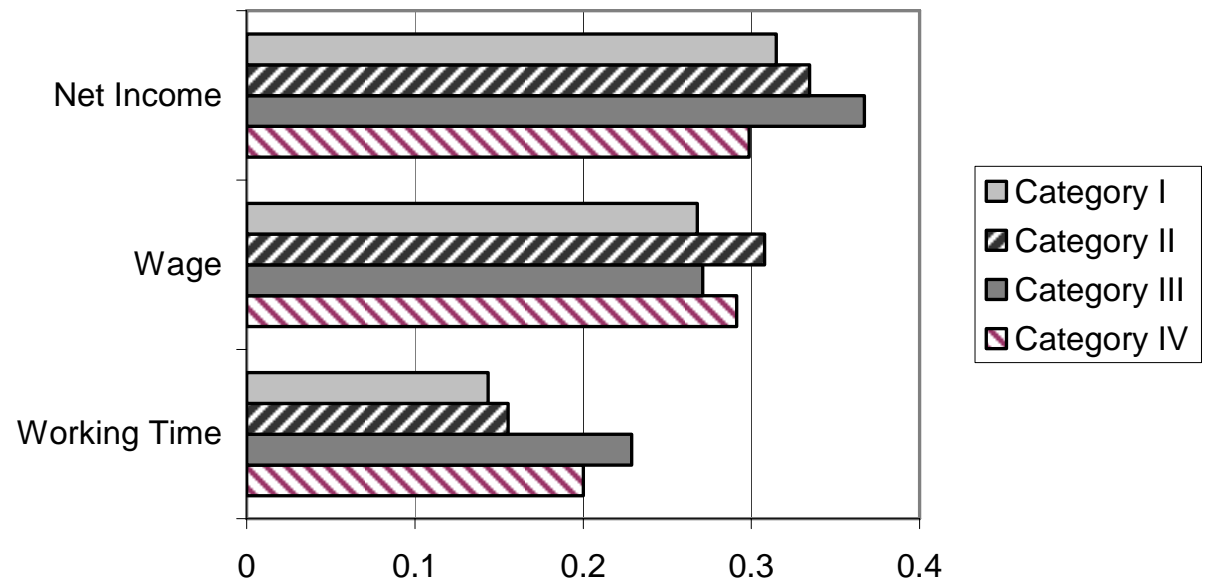

Source: German Time Use Survey 2001/02, own illustration.

\section{References}

Addison, J.T. and C.J. Surfield (2009), Atypical work and employment continuity, IZA Discussion Paper No. 4065, Bonn.

Angrist, J (2001), Estimation of limited-dependent variable models with dummy endogenous regressors - Simple strategies for empirical practice, in: Journal of Business and Economic Statistics, Vol. 29, No. 1, $2-15$.

Angrist, J., and J.S. Pischke (2009), Mostly harmless econometrics - An empiricist's companion, Princeton University Press, Princeton.

Atkinson, A.B. (1970), On the measurement of inequality, in: Journal of Economic Theory, Vol. 2, No. 3, $244-$ 263.

Bauer, F., Groß, H., Munz, E. and S. Sayin (2001), Arbeits- und Betriebszeiten - Neue Formen des betrieblichen Arbeits- und Betriebszeitmanagements, Düsseldorf.

Becker, G. (1965), A Theory of the Allocation of Time, in: Economic Journal, Vol. 75, 493-517.

Becker, G. (1975), Human capital - A theoretical and empirical analysis with special reference to education, 2nd ed., The University of Chicago Press, Chicago.

Blundell, R. and T. MaCurdy (1999), Labour supply - A review of alternative approaches, in: Ashenfelter, O. and D. Card (eds.), Handbook of Labour Economics, Elsevier, Amsterdam, Vol. 3, 1559-1695.

Bonke, J. and F. Gerstoft (2005), Stress, time use and gender, in: electronic Journal of Time Use Research, Vol. 4, No. 1, 47-68.

Burtless, G. (1993), The contribution of employment and hours changes to family income inequality, in: American Economic Review, Vol. 83, No. 2, 131-135.

Büssing, A. and H. Seifert (1995), Sozialverträgliche Arbeitszeitgestaltung, Hampp, München.

Callister, P. and S. Dixon (2001), New Zealander' working time and home work patterns - Evidence from the Time Use Survey, Occasional Paper No. 5, Wellington Labour Market Policy Group, Department of Labour, Wellington.

Champernowne, D.G. and F.A. Cowell (1998), Inequality and income distribution, Cambridge University Press, Camebridge.

Clarkberg, M. and Ph. Moen (2000), Understanding the time squeeze - Married couples preferred and actual work-hour strategies, in: American Behavioral Scientist, Vol. 44, No. 7, 1115-1136.

Cowell, F.A. (1995), Measuring inequality, 2nd ed., Hemel Hempstead, Harvester Wheatsheaf. 
Joachim Merz, Paul Böhm and Derik Burgert: Timing and fragmentation of work and income inequality

Doiron, D. and J. Barrett (1996), Inequality in male and female earnings - The role of hours and wages, in: The Review of Economics and Statistsics, Vol. 78, No. 3, 410-420.

Ehling, M. (1999),The German time use survey - Methods and results, in: Merz, J. and M. Ehling (eds.), Time use - Research, data and policy, Nomos, Baden-Baden, 89-105.

Ehling, M., Holz, E. and I. Kahle (2001), Erhebungsdesign der Zeitbudgeterhebung 2001/2002, in: Wirtschaft und Statistik, Vol. 6, 427-436.

eIJTUR time pieces (2005), in: electronic International Journal of Time Use Research, Vol. 2, 90-91.

Federal Statistical Office Germany (1992), Handbuch zu ,Wo bleibt die Zeit?', Wiesbaden.

Federal Statistical Office Germany (2009), Niedrigeinkommen und Erwerbstätigkeit - Begleitmaterial zum Pressegespräch vom 19.8.2009, Wiesbaden.

Garhammer, M. (1994), Balanceakt Zeit - Auswirkungen flexibler Arbeitszeiten auf Alltag, Freizeit und Familie, Edition Sigma, Berlin.

Glorieux, I. and J. Minnen (2004), Working five to nine - Atypical working hours in Flanders/Belgium, TOR Discussion Paper 2004/31, Vrije Universiteit Brussel, Brussels.

Glorieux, I., Mestdag, I. and J. Minnen (2008), The coming of the 24-hour economy? Changing work schedules in Belgium between 1966 and 1999, in: Time \& Society, Vol. 17, No. 1, 63-83.

Greene, W. (1998), LIMDEP Version 7/8, Plainview, New York.

Greene, W. (2000), Econometric analysis, 4th ed., Prentice Hall, Upper Saddle River.

Greene, W. (2003), Econometric analysis, 5th ed., Prentice Hall, Upper Saddle River.

Ham, J.C. (1982), Estimation of a labour supply model with censoring due to unemployment and underemployment, in: Review of Economic Studies, Vol. 69, 335-54.

Hamermesh, D. (1996a),The timing of work time, in: Konjunkturpolitik - Applied Economics Quarterly, Vol. 42, 1-22.

Hamermesh, D. (1996b), Workdays, workhours and work schedules, W.E. Upjohn Institute for Employment Research, Kalamazoo.

Hamermesh, D. (1998), When we work, in: American Economic Review, Vol. 88, 321-325.

Hamermesh, D. (2002), Timing, togetherness and time windfalls, in: Journal of Population Economics, Vol. 15, 321-325.

Harvey, A. and A.St. Croix (2005), Report on data assembly and preliminary evaluation, Yale program of nonmarket accounts - Dataset assessments, Halifax.

Harvey, A. (1999), Time use research - The roots to the future, in: Merz, J. and M. Ehling (eds.), Time use Research, data and policy, Nomos, Baden-Baden, 123-149.

Harvey, A. Fisher, K., Gershuny, J. and A. Akbari (2000), Examining working time arrangements using time use surveys, ISER Working Paper No. 20, Essex.

Hausman, J. and D. McFadden (1984), A specification test for the multinomial logit model, in: Econometrica, Vol. 54, 1219-1240.

Heckman, J., Lalonde, R.J. and J.A. Smith (1999), The economics and econometrics of active labor market programs, in: Ashenfelter, O. and D. Card (eds.), Handbook of labor economics, Vol. 3a, Elsevier Science B.V., Amsterdam, 1865-2097.

Heckman, J.J. (1979), Sample selection bias as a specification error, in: Econometrica, 153-161.

Holst, E. and J. Schupp, J. (1994), Ist Teilzeitarbeit der richtige Weg? Arbeitszeitpräferenzen in West- und Ostdeutschland, in: DIW-Wochenbericht, Vol. 35, No. 94, 618-26.

Jenkins, S.P. and N.C. O'Leary (1996), Household income plus household production - The distribution of extended income in the UK, in: The Review of Income and Wealth, Vol. 42, No. 4, 401-419.

Killingsworth, M.R. (1983), Labour supply, Cambridge University Press, Cambridge.

Killingsworth, M.R. and J.J. Heckman (1986), Female Labour Supply - A Survey, in: Ashenfelter, O. and R. Layard (eds.), Handbook of Labour Economics - Vol I, North-Holland, Amsterdam/New York, 103204.

La Valle, I., Arthur, A., Milward, C., Scott, J. and M. Clayden (2002), Happy families? Atypical work and its influence on family life, Policy Press, Bristol.

Le Bihan, B. and C. Martin (2005), Atypical working hours - Consequences for childcare arrangements, in: Kröger, T: and J. Sipilä (eds.), Overstretched - European families up against the demands of work and care, Blackwell, Carlton, Australia, 9-33. 
Lee, C. (2001), Changes in employment and hours, and family income inequality in the United States - 19691989, in: International Economic Journal, Vol. 15, No. 2, 27-50.

Lee, L.-F.(1983), Generalized econometric models with selectivity, Econometrica, Vol. 51, No. 2, 507-512.

Lesnard, L. (2008), Off-scheduling within dual-earner couples: An unequal and negative externality for family time export, in: American Journal of Sociology, Vol. 114, No. 2, 447-490.

Lüthi, A. (1981), Messung wirtschaftlicher Ungleichheit - Lecture Notes, in: Economic and Mathematical Systems, No. 189, Springer Verlag, Berlin/Heidelberg/New York.

Maasoumi, E. (1999), Empirical analyses of inequality and welfare, in: Pesaram, M.H. und P. Schmidt (eds.), Handbook of Applied Econometrics - Vol. II - Microeconomics, Plackwell Publisher, Oxford 202245.

Madalla, G.S. (1983), Limited dependent and qualitative variables in econometrics, Cambridge University Press, Cambridge/London.

McFadden, D. (1976), Quantal choice analysis - A survey, in: Annals of Economic and Social Measurement, Vol. 5, No. 4, 363-390.

McFadden, D. (1985), Econometric analysis of qualitative response models, in: Griliches, Z. and M.D. Intriligator (eds.), Handbook of Econometrics - Volume II, North-Holland, Amsterdam/New York, 1395-457.

Merz, J. (1990), The 1990 German tax reform - Microsimulation of time allocation effects in the formal and informal economy, in: Brunner, J.G. and H.-G. Petersen (eds.), Prospects and limits of simulation models in tax and transfer policy, Campus Verlag, Frankfurt/New York, 509-37.

Merz, J. (1990), Female labour supply - Labour force participation, market wage rate and working hours of married and unmarried women in the Federal Republic of Germany - The influence of occupational career, transfers and socio-economic variables based on the Socio-Economic Panel, in: Jahrbücher für Nationalökonomie und Statistik, Vol. 210, 240-270.

Merz, J. and D. Kirsten (1999), Extended income dynamics - Valueing household production and its distributional impacts - A ten years panel analysis for professions, entrepreneurs and employees, in: Merz, J. and M. Ehling (eds.), Time use - Research, data and policy, Nomos, Baden-Baden, 351-382.

Merz, J. and M. Ehling (1999), Time use - Research, data and policy, Nomos, Baden-Baden.

Merz, J. (2002a), Time use research and time use data - Actual topics and new frontiers, in: Ehling, M. and J. Merz (eds.), Neue Technologien in der Umfrageforschung - Anwendungen bei der Erhebung von Zeitverwendung, Nomos, Baden-Baden, 3-19.

Merz, J. (2002b), Time and economic well-being - A panel analysis of desired vs. actual working hours, in: The Review of Income and Wealth, Vol. 48, No. 3, 317-346.

Merz, J. and D. Burgert (2003a), Working hours arrangements and working hours - A microeconometric analysis based on German time diary data, FFB-Discussion Paper No. 41, Lüneburg.

Merz, J. and D. Burgert (2003b), Who is working when? Tendencies in working-time-pattern in Germany - A microeconometric analysis, Proceedings of the 25th International Association for Time Use Research (IATUR) Conference on Time Use Research, Comparing Time, Brussels, September 17-19, 2003, www.vub.ac.be/TOR/iatur/abstracts/doc/paper-28.ppt.

Merz, J. and D. Burgert (2004), Arbeitszeitarrangements - Neue Ergebnisse aus der Zeitbudgeterhebung 2001/02 im Zeitvergleich zu 1991/92, in: Statistisches Bundesamt (ed.), Alltag in Deutschland - Analysen zur Zeitverwendung, FORUM Band 43, Wiesbaden, 304-336.

Merz, J. and P. Böhm (2005), Arbeitszeitarrangements und Entlohnung - Ein Treatment-Effects-Ansatz für Freiberufler, Unternehmer und abhängig Beschäftigte, in: Reinhard Schulte (ed.), Ergebnisse der MittelstandsForschung, Lit-Verlag, Münster, 237-264.

Merz, J. and P. Böhm (2008), Tägliche Arbeitszeitmuster und Einkommen von Freien Berufen Neue Ergebnisse auf der Basis von Zeittagebüchern, in: Merz, J. (ed.), Freie Berufe - Einkommen und Steuern (FB€St) - Beiträge aus Wissenschaft und Praxis, Nomos, Baden-Baden, 93-118.

Merz, J. and H. Stolze (2008), Representative time use data and new harmonised calibration of the American Heritage Time Use Data (AHTUD) 1965-1999, in: electronic International Journal of Time Use Research, Vol. 5, No. 1, 90-126.

Merz, J. (2009), Time use and time budgets - Improvements, future challenges and recommendations, FFB Discussion Paper No. 79, Lüneburg.

Merz, J. and T. Rathjen (2009), Time and income poverty - An interdependent multidimensional poverty approach with German time use diary data, FFB Discussion Paper No. 79, Lüneburg. 
Joachim Merz, Paul Böhm and Derik Burgert: Timing and fragmentation of work and income inequality

Mincer, J. (1974), Schooling, experience and earnings, National Bureau of Economic Research, Columbia University Press.

National Research Council (2000), Time-use measurement and research, in: Committee on National Statistics (Ver Ploeg, M., Altonij, J., Bradburn, N., DaVanzo, J., Nordhaus, W. and F. Samaniego) (eds.), Commission on behavioral and social sciences and education, National Academic Press, Washigton, D.C..

Osberg, L. (2002), Time, money and inequality in international perspective, Discussion Paper, Department of Economics, Dalhousie University, Halifax.

Pencavel, J. (1986), Labour supply of men - A survey, in: Ashenfelter, O. and R. Layard (eds.), Handbook of Labour Economics - Vol I, North-Holland Amsterdam/New York, 3-102.

Pierenkemper, T. (2009), The rise and fall of the "Normalarbeitsverhältnis" in Germany, IZA Discussion Paper No. 4068, Bonn.

Polachek, S.W. and W.S. Siebert (1999), The economics of earnings, Cambridge University Press, Cambridge

Schupp, J. (1994), Teilzeitbeschäftigung im sozialen Wandel - Längsschnittanalysen und handlungstheoretische Fundierung (Dissertation), Ruhr-Universität, Bochum.

Sen, A. (1992), Inequaliy rexamined, Harvard University Press, Cambridge, Mass.

Shorrocks, A.F. (1984), Inequality decomposition by population subgroups, in: Econometrica, Vol. 52, No. 6, $1369-1385$.

Shorrocks, A.F. (1980), The class of additively decomposable inequality measures, in: Econometrica, Vol. 48, No. 3, 613-625.

Silber, J. (1999), Handbook on income inequality measurement, Kluwer Academic Publishers, Boston/London.

StataCorp (2004) Stata 8.2., College Station, Texas (www.stata.com).

Sullivan, O. (2007), Cultural voraciousness - A new measure of the pace of leisure in a context of 'harriedness', in: electronic International Journal of Time Use Research, Vol. 4, No. 1, 30-46.

Townsend, B. (2001), Dual-earner couples and long work hours - A structural and life course perspective, in: Berkeley Journal of Sociology, Vol. 45, 161-179.

van Soest, A., Woittiez, I. and A. Kapteyn (1989), Labour supply, income taxes and hours restrictions in the Netherlands, Discussion Paper No. 8903, Tilburg University, Tilburg. 